System-Wide Water Resources Program

\title{
Development of a River and Stream Water Quality Module
}

Billy E. Johnson and Zhonglong Zhang

June 2009 


\section{Development of a River and Stream Water Quality Module}

Billy E. Johnson

Environmental Laboratory

U.S. Army Engineer Research and Development Center

3909 Halls Ferry Road

Vicksburg, MS 39180-6199

Zhonglong Zhang

SecPro Inc.

3909 Halls Ferry Road

Vicksburg, MS 39180-6199

Final report

Approved for public release; distribution is unlimited.

Prepared for Headquarters, U.S. Army Corps of Engineers

Washington, DC 20314-1000 


\begin{abstract}
This report describes the in-stream water quality module within the Nutrient Sub-Model (NSM), Version 1.2. The in-stream water quality module includes the major processes for nitrogen, phosphorus, carbon, and oxygen cycling in a stream. Kinetic process equations are presented for each state variable for water quality modeling in streams. These equations were taken largely from models such as QUAL2K, ICM, etc. and summarize past development efforts. As research continues, it is anticipated that improved process descriptions will be developed and will be integrated into the NSM.
\end{abstract}

DISCLAIMER: The contents of this report are not to be used for advertising, publication, or promotional purposes. Citation of trade names does not constitute an official endorsement or approval of the use of such commercial products. All product names and trademarks cited are the property of their respective owners. The findings of this report are not to be construed as an official Department of the Army position unless so designated by other authorized documents. 


\section{Contents}

Contents. iii

Figures and Tables...........................................................................................................................

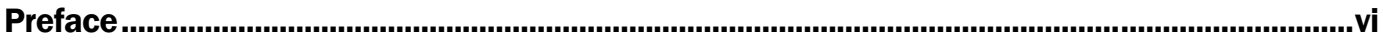

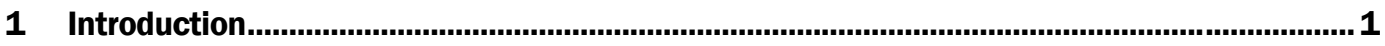

2 Water Quality Transport Mass Balance Equations............................................................... 3

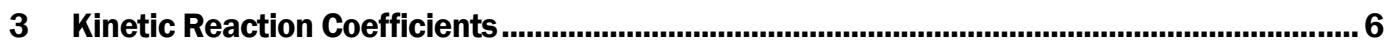

Stoichiometric coefficients of organic matter........................................................... 6

Stoichiometric coefficients for oxygen generation and consumption ................................ 7

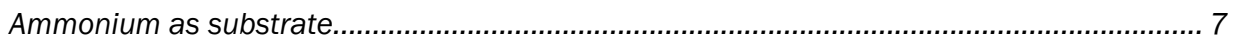

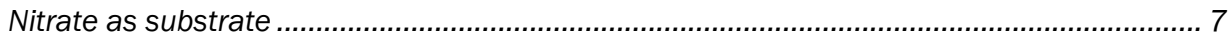

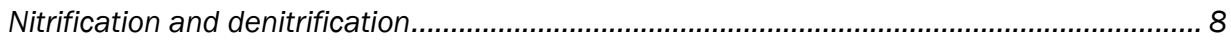

Stoichiometric coefficient for DOC utilization ............................................................... 8

Temperature effects on kinetic reaction rates ........................................................ 8

4 Water Quality Kinetic Reaction Equations ................................................................................ 9

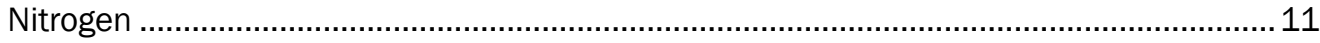

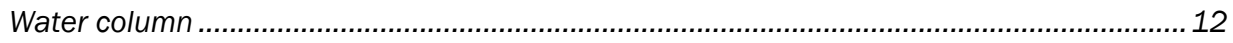

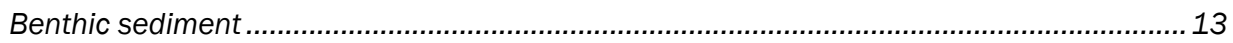

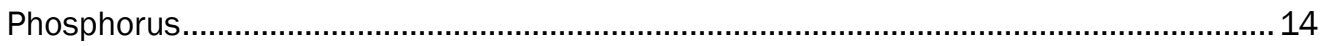

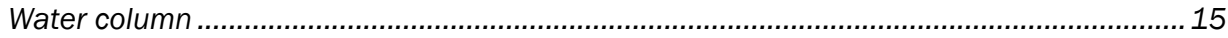

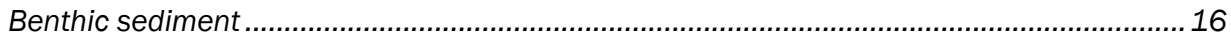

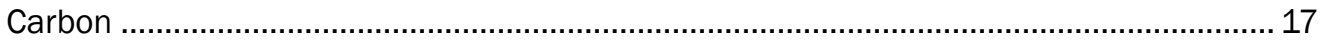

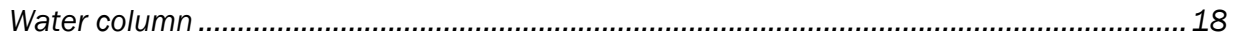

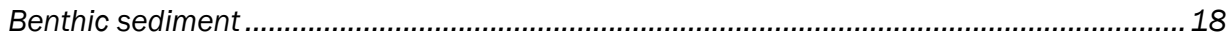

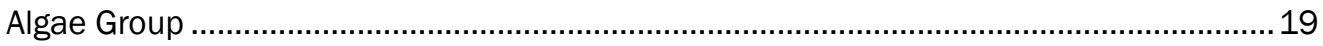

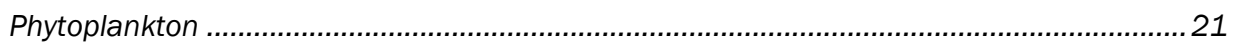

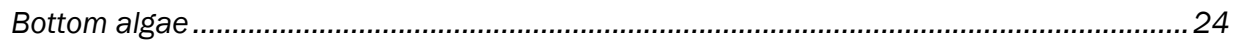

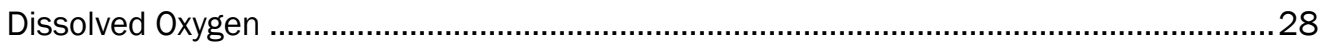

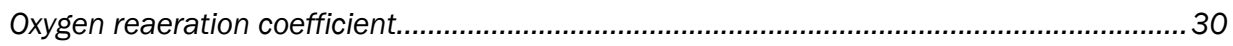

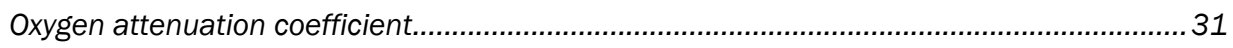

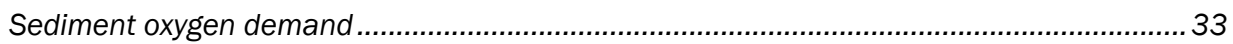




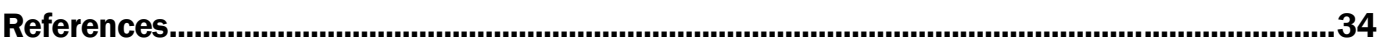

Appendix A: One-Dimensional Water Quality Transport Equations............................................37

Appendix B: One-Dimensional Finite Difference Equations and Numerical Solutions.................42

Report Documentation Page 


\section{Figures and Tables}

\section{Figures}

Figure 1. Simplified schematic representation of the in-stream nitrogen cycling processes ........... 12

Figure 2. Simplified schematic representation of the in-stream phosphorus cycling

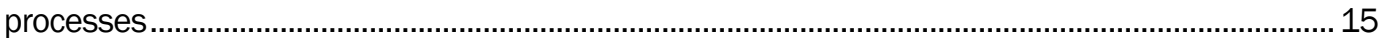

Figure 3. Simplified schematic representation of the in-stream carbon cycling processes ............. 18

Figure 4. Simplified schematic representation of the in-stream algae kinetic processes..................20

Figure 5. Three models used for phytoplankton photosynthetic light dependence .......................... 23

Figure 6. Simplified schematic representation of the in-stream DO dynamic processes................. 29

Figure A1. Water quality constituent flux through a 1D control volume.............................................38

Figure A2. Schematic representation of benthic sediment .............................................................. 41

Figure B1. Conceptual stream network system ………….......................................................... 43

Figure B2. 1D FD computational mesh.................................................................................. 44

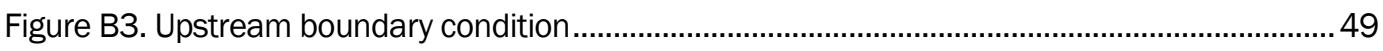

Figure B4. Downstream boundary condition ........................................................................... 50

\section{Tables}

Table 1. Recommended values for stoichiometry ....................................................................... 7

Table 2. In-stream water quality state variables................................................................................. 10

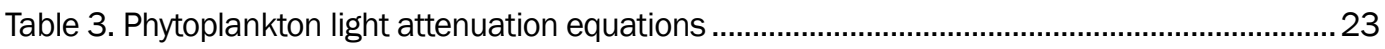

Table 4. Bottom algae light attenuation equations........................................................................ 27

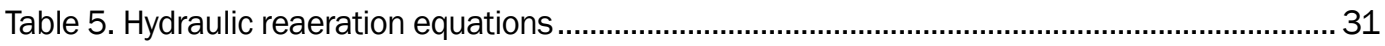

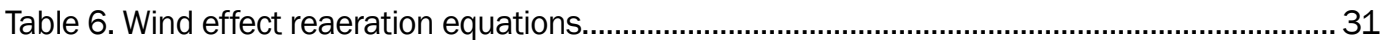




\section{Preface}

This report summarizes the efforts undertaken in developing a nutrient sub-model for linkage with a variety of hydraulic and hydrologic modeling systems since the release of SWWRP-NSM version 1.1. This development effort was performed by the U.S. Army Engineer Research and Development Center (ERDC), Vicksburg, Mississippi. Funding was provided under the System-Wide Water Resources Program (SWWRP). Appreciation is extended to all those who assisted in the formulations and review of the process descriptions implemented within the Nutrient Sub-Model (NSM).

Principal Investigators for this study were Dr. Billy E. Johnson of the Water Quality and Contaminant Modeling Branch (WQCMB), Environmental Laboratory (EL) and Dr. Zhonglong Zhang of SpecPro Inc. Dr. Zhang was funded as an onsite contractor under Task Order Contract W912HZ-05-D-0011 on Civil Delivery Order No. 15. Dr. Johnson conducted his portion of the study under the general supervision of Dr. Barry W. Bunch, Chief of WQCMB, and under the general supervision of Dr. Richard E. Price, Chief, Environmental Processes and Engineering Division, and Dr. Beth C. Fleming, Director of EL.

COL. Gary E. Johnston was Commander and Executive Director of ERDC. Dr. James R. Houston was Director. 


\section{Introduction}

Within the System-Wide Water Resources Research Program (SWWRP), multiple riverine, estuarine, watershed, and subsurface flow models are being modified to address issues of environmental concern. Several integration approaches are either ongoing or have been proposed to accomplish this task. To have a full system-wide water quality and contaminant capability in SWWRP, the various hydrologic and hydrodynamic engines must utilize a common water quality and contaminant approach to prevent the arbitrary partitioning of constituents. The goal of this development effort is to upgrade existing hydrologic and hydraulic models (i.e., water engines) using a common water quality approach in order to facilitate their linkage and application on a system-wide basis.

In keeping with a common water quality approach to model development, a library of water quality kinetic modules are being developed such that they can be integrated with a variety of water transport engines. Modules in the library of algorithms have the following characteristics:

- multi-species, multi-phase, and multi-reaction system

- fast (equilibrium-based) and slow (non-equilibrium-based or ratebased) reactions

- easily extensible to new reaction pathways

- include both common nutrient and contaminant packages as well as geochemistry

- simple, well-defined data interface and calling procedure

The water quality modules are developed such that they are data structure independent thus facilitating their integration into a wide range of modeling systems.

The Nutrient Sub-Model (NSM) has been developed as a library of water quality kinetic modules. NSM considers a detailed $\mathrm{N}$ and $\mathrm{P}$ cycling and computes nutrient kinetic fluxes for nitrogen, phosphorus, and other species in watersheds to water bodies (Johnson and Gerald 2006; Johnson et al. 2007). Modeling of nutrients in previously released versions of NSM consists of three distinct parts: 1) Simulation of the major $N$ and $P$ cycling processes in the soil; 2) Transformation and loading of $\mathrm{N}$ and $\mathrm{P}$ species in 
the overland flow; and 3) Simulation of in-stream water quality based on the QUAL2E algorithms.

Given improvements in our understanding of channel kinetics since the release of QUAL2E, this development effort has focused on improving the NSM channel kinetics to take advantage of state-of-the-art process descriptions. Stream water quality can be dealt with at different levels of detail. The in-stream nutrient kinetic algorithms in NSM Version 1.2 are adapted from the QUAL2E, QUAL2K, CE-QUAL-RIV1 (RIV1), CE-QUALW2 (W2), and CE-QUAL-ICM (ICM) models. Both QUAL2 and RIV1 are one-dimensional (1D) comprehensive stream water quality models. W2 is a water quality and hydrodynamic model in 2D (longitudinal-vertical) for rivers, estuaries, lakes, reservoirs, and river basin systems (Cole and Wells 2003). W2 models basic eutrophication processes such as temperature, nutrients, algae, dissolved oxygen, organic matter and sediment relationships. ICM is a finite volume eutrophication model that can be used to simulate 1-, 2-, 3-dimensional water quality variables including multiple forms of algae, carbon, nitrogen, phosphorus, and silica; and dissolved oxygen (Cerco and Cole 1995). The QUAL2 and RIV1 models lack a clear operational definition of water quality parameters within the model. For example, it is known that there are many forms of organic nitrogen present in natural waters. Both models combine all of them under 'organic $\mathrm{N}$ ' and do not specify further whether they are TON, Kjeldahl N, particulate, dissolved, or other. In contrast, the ICM model contains a precise specification of the nitrogen, phosphorus, and carbon variables. Since ICM contains more processes, it also contains more parameters. In principle, the larger number of parameters in models entails more difficulties during model calibration.

This report describes the in-stream water quality module within NSM version 1.2. The in-stream water quality module includes the major processes for nitrogen, phosphorus, carbon, and oxygen cycling in a stream. Kinetic process equations are presented for each state variable for water quality modeling in streams. These equations were taken largely from the QUAL2K, ICM, etc. and summarize past development efforts. As research continues, it is anticipated that improved process descriptions will be developed and will be integrated into the NSM. 


\section{Water Quality Transport Mass Balance Equations}

Water quality in estuaries, lakes, and reservoirs depends upon the quantity and quality of inflows from the upstream watershed, which is usually the most significant source of pollutants. Streamflow is therefore of primary importance to the health of receiving waters and its quantification is crucial to the ability to manage those systems in an environmentally healthy manner.

For stream water quality studies, it is assumed that longitudinal and temporal changes (1D transport) are applicable. Water quality is affected in streams due to physical transport and exchange processes and biological, chemical, and biochemical kinetic processes along with changes due to benthic sediments. Transport not only includes advection but diffusion/dispersion of water quality constituents as well. Derivation of the in-stream transport equations can be found in Appendix A.

The following $1 \mathrm{D}$ transport equation is often solved for dissolved state variables:

$$
\begin{aligned}
\frac{\partial C_{j}}{\partial t}= & -\frac{Q}{A} \frac{\partial C_{j}}{\partial x}+\frac{1}{A} \frac{\partial}{\partial x}\left(A D_{x} \frac{\partial C_{j}}{\partial x}\right) \\
& +\frac{q_{l}}{A}\left(C_{j, l}-C_{j}\right)+\frac{1}{h_{c h}} S_{d}+\sum R_{j, k}+S_{j}
\end{aligned}
$$

where:

$C_{j}=$ concentration of dissolved constituent $\mathrm{j}$ in stream $\left[\mathrm{M} / \mathrm{L}^{3}\right]$

$Q=$ stream flow discharge $[\mathrm{L} 3 / \mathrm{T}]$

$A=$ cross-sectional area of the stream $\left[\mathrm{L}^{2}\right]$

$D_{x}=$ longitudinal dispersion coefficient of constituent $\mathrm{j}\left[\mathrm{L}^{2} / \mathrm{T}\right]$

$q_{l}=$ volumetric lateral inflow $\left[\mathrm{L}^{2} / \mathrm{T}\right]$

$h_{c h}=$ hydraulic depth of the stream [L]

$C_{j, l}=$ inflow concentration of dissolved constituent $\mathrm{j}[\mathrm{M} / \mathrm{L} 3]$

$S_{d}=$ source/sink term due to transfer from sediment pore water $\left[\mathrm{M} / \mathrm{L}^{2} / \mathrm{T}\right]$

$C_{s j}=$ concentration of particulate constituent $\mathrm{j}$ in stream $\left[\mathrm{M} / \mathrm{L}^{3}\right]$ 
$C_{s j, l}=$ inflow concentration of particulate constituent $\mathrm{j}[\mathrm{M} / \mathrm{L} 3]$

$S_{s}=$ sink term due to settling from water column to bed sediment $\left[\mathrm{M} / \mathrm{L}^{2} / \mathrm{T}\right]$

$S_{r}=$ source term due to resuspension of bed sediment $\left[\mathrm{M} / \mathrm{L}^{2} / \mathrm{T}\right]$

$R_{j, k}=$ source/sink term representing a mass rate of change of constituent $\mathrm{j}$ due to kinetic reaction $\mathrm{k}[\mathrm{M} / \mathrm{L} 3 / \mathrm{T}]$

$S_{j}=$ source/sink term representing external gains and losses of constituent $\mathrm{j}[\mathrm{M} / \mathrm{L} 3 / \mathrm{T}]$.

The transport of particulate pollutants includes the settling, resuspension, and sedimentation of solids. Water quality constituents sorbed onto solid particles are transported between the water column and the sediment bed. Due to its solid nature, there is no transfer from sediment pore water. The 1D transport equation for particulate state variables is:

$$
\begin{aligned}
\frac{\partial C_{s j}}{\partial t}= & -\frac{Q}{A} \frac{\partial C_{s j}}{\partial x}+\frac{1}{A} \frac{\partial}{\partial x}\left(A D_{x} \frac{\partial C_{s j}}{\partial x}\right) \\
& +\frac{q_{l}}{A}\left(C_{s j, l}-C_{s j}\right)-\frac{1}{h_{c h}}\left(S_{s}-S_{r}\right)+\sum R_{j, k}+S_{j}
\end{aligned}
$$

Transport Equations 1 and 2 compute the transport of constituents with their internal and external source/sink terms. External terms are due to boundary sources/sinks and transfer mechanisms. Internal source/sink terms represent kinetic reaction rates. The division of terms allows kinetic sources/sinks to be updated at different frequencies than the transport terms - consistent with the coarser time steps associated with biological and chemical processes.

In the following mass balance equations, the transport operator is defined as:

$$
L\left(C_{j}\right)=-\frac{Q}{A} \frac{\partial C_{j}}{\partial x}+\frac{1}{A} \frac{\partial}{\partial x}\left(A D_{x} \frac{\partial C_{j}}{\partial x}\right)+\frac{q_{l}}{A}\left(C_{j, l}-C_{j}\right)+S_{j}
$$

The exchange of dissolved mass between the stream channel and the benthic sediment is modeled as a first-order mass transfer process. Settling and resuspension of each component of the nutrient pool is accomplished using the particle sedimentation and resuspension equation. 
The NSM in-stream water quality module simulates nutrient (nitrogen, phosphorus, and carbon) cycling, dissolved oxygen (DO) dynamics, phytoplankton production and loss. The mass balance equations for each NSM state variable are presented in the following sections. In order to provide a complete description of the dominant pools and fluxes in the water column, a single benthic sediment layer is included to maintain mass balance. The bed sediment plays an important role in the transport and fate of water quality constituents. Sediment-sorbed pollutants may be buried in the bed by deposition and sedimentation, or they may be released to the water column by scour. Within NSM the governing equations are greatly simplified, as the processes of advection, dispersion, and lateral inflow are not modeled for the benthic sediment. The concentrations of the dissolved and particulate state variables in a stationary upper bed are given by:

$$
\begin{gathered}
\frac{\partial C_{j 2}}{\partial t}=\frac{1}{h_{s e d}} S_{d}+\sum R_{j, k} \\
\frac{\partial C_{s j 2}}{\partial t}=\frac{1}{h_{s e d}}\left(S_{s}-S_{r}\right)+\sum R_{j, k}
\end{gathered}
$$

where:

$C_{j 2}=$ concentration of dissolved constituent $\mathrm{j}$ in bulk volume of benthic sediment $\left[\mathrm{M} / \mathrm{L}^{3}\right]$

$C_{s j 2}=$ concentration of particulate constituent $\mathrm{j}$ in benthic sediment $\left[\mathrm{M} / \mathrm{L}^{3}\right]$

$h_{\text {sed }}=$ depth of upper bed layer [L]. 


\section{Kinetic Reaction Coefficients}

A principal component in the mass balance transport equations written for nutrients is the nutrient uptake kinetics associated with algae (phytoplankton) growth. To specify the nutrient uptake kinetics with this growth it is necessary to specify the population stoichiometry in units of nutrient uptake per mass of population synthesized. Using carbon as the unit of population biomass, the relevant ratios are the mass of nitrogen and phosphorus per unit mass of carbon. A selection of these ratios is described as follows.

\section{Stoichiometric coefficients of organic matter}

The mass ratios of carbon to nitrogen to phosphorus to algae are required by the following mass balance equations. The stoichiometric coefficients of algae are calculated with the technique provided in Chapra (1997), based on a Redfield composition of all organic particles (Table 1). These recommended values are then combined to determine stoichiometric coefficients as follows.

$$
\begin{gathered}
r_{n a}=7.2 \frac{\mathrm{mgN}}{\mathrm{mgA}} \\
r_{p a}=1.0 \frac{\mathrm{mgN}}{\mathrm{mgA}} \\
r_{c a}=0.04 \frac{\mathrm{gC}}{\mathrm{mgA}} \\
r_{c c a}=r_{c a}\left(\frac{\mathrm{gC}}{\mathrm{mgA}}\right) \times \frac{\mathrm{moleC}}{12 \mathrm{gC}} \times \frac{\mathrm{gO}}{1000 \mathrm{~L}} \\
r_{c c o}=\frac{1}{r_{o c}}\left(\frac{\mathrm{gC}}{\mathrm{gO}}\right) \frac{\mathrm{moleC}}{12 \mathrm{gC}} \times \frac{\mathrm{m}^{3}}{1000 \mathrm{~L}}
\end{gathered}
$$


Table 1. Recommended values for stoichiometry

\begin{tabular}{|l|c|c|}
\hline Variable & Symbol & Recommended values \\
\hline Carbon & $C$ & $40 \mathrm{gC}$ \\
\hline Nitrogen & $N$ & $7.2 \mathrm{gN}$ \\
\hline Phosphorus & $P$ & $1 \mathrm{gP}$ \\
\hline Chlorophyll a & $A$ & $1 \mathrm{gA}$ \\
\hline
\end{tabular}

\section{Stoichiometric coefficients for oxygen generation and consumption}

NSM requires that the rates of oxygen generation and consumption be prescribed. The stoichiometric coefficients for oxygen generation and consumption are based upon a typical chemical reaction for plant photosynthesis and respiration (Chapra 1997). Photosynthesis is one of the most important biological activities in stream systems. Many water quality parameters such as dissolved oxygen, carbon dioxide, $\mathrm{pH}$ cycles, and nutrients are regulated by the photosynthetic reaction in phytoplankton. Simply stated, photosynthesis is the process by which phytoplankton uses sunlight to convert carbon dioxide into a food source and to release oxygen as a byproduct. Note that the equation for respiration (R) is the opposite of photosynthesis $(\mathrm{P})$ indicating the products of photosynthesis become reactants in respiration and vice-versa. Because it requires light, photosynthesis occurs only during daylight hours. Respiration, on the other hand, occurs 24 hours a day.

\section{Ammonium as substrate}

$$
\begin{aligned}
& 106 \mathrm{CO}_{2}+\left\{16 \mathrm{NH}_{4}^{+}+\mathrm{HPO}_{4}^{2-}\right\}+108 \mathrm{H}_{2} \mathrm{O}_{\mathrm{R}}^{\stackrel{\mathrm{P}}{\longleftrightarrow}}\left\{\mathrm{C}_{106} H_{263} \mathrm{O}_{110} N_{16} P_{1}\right\}+107 \mathrm{O}_{2}+14 \mathrm{H}^{+} \\
& \text {nutrients } \\
& \text { algal protoplasm }
\end{aligned}
$$

\section{Nitrate as substrate}

$$
106 \mathrm{CO}_{2}+\left\{16 \mathrm{NO}_{3}^{-}+\mathrm{HPO}_{4}^{2-}\right\}+122 \mathrm{H}_{2} \mathrm{O}+18 \mathrm{H}^{+} \underset{R}{\stackrel{P}{\longrightarrow}}\left\{C_{106} \mathrm{H}_{263} \mathrm{O}_{110} N_{16} P_{1}\right\}+138 \mathrm{O}_{2}
$$

Oxygen is produced during photosynthesis and consumed during respiration. If ammonium is the substrate, the following ratio can be used to determine the grams of oxygen generated for each gram of plant matter that is produced through photosynthesis. 


$$
r_{\text {oca }}=\frac{107 \mathrm{moleO}_{2}\left(32 \mathrm{gO}_{2} / \mathrm{moleO}_{2}\right)}{106 \mathrm{moleC}(12 \mathrm{gC} / \mathrm{moleC})}=2.69 \frac{\mathrm{gO}_{2}}{\mathrm{gC}}
$$

If nitrate is the substrate, the following ratio applies:

$$
r_{\text {ocn }}=\frac{138 \mathrm{moleO}_{2}\left(32 \mathrm{gO}_{2} / \mathrm{moleO}_{2}\right)}{106 \mathrm{moleC}(12 \mathrm{gC} / \mathrm{moleC})}=3.47 \frac{\mathrm{gO}_{2}}{\mathrm{gC}}
$$

Nitrification and denitrification

$$
\begin{gathered}
\mathrm{NH}_{4}^{+}+2 \mathrm{O}_{2} \stackrel{\text { nitrification }}{\longrightarrow} \mathrm{NO}_{3}^{-}+\mathrm{H}_{2} \mathrm{O}+2 \mathrm{H}^{+} \\
5 \mathrm{CH}_{2} \mathrm{O}+4 \mathrm{NO}_{3}^{-}+4 \mathrm{H}^{+} \stackrel{\text { denitrification }}{\longrightarrow} 5 \mathrm{CO}_{2}+2 \mathrm{~N}_{2}+7 \mathrm{H}_{2} \mathrm{O}
\end{gathered}
$$

Nitrification is dependent upon a suitable supply of DO. The ratio of oxygen to nitrogen in the nitrification process is determined by:

$$
r_{o n}=\frac{2 \mathrm{moleO}_{2}\left(32 \mathrm{gO}_{2} / \mathrm{moleO}_{2}\right)}{1 \mathrm{moleN}(14 \mathrm{gN} / \mathrm{moleN})}=4.57 \frac{\mathrm{gO}_{2}}{\mathrm{gN}}
$$

\section{Stoichiometric coefficient for DOC utilization}

DOC is utilized during denitrification. The following ratio $\left(r_{c n d n}\right)$ is used to determine the organic carbon lost per nitrate nitrogen that is denitrified.

$$
r_{\text {cndn }}=\frac{5 \mathrm{moleC} \times 12 \mathrm{gC} / \mathrm{moleC}}{4 \mathrm{moleN} \times 14 \mathrm{gN} / \mathrm{moleN}} \times \frac{1 \mathrm{gN}}{1000 \mathrm{mgN}}=1.0714 \frac{\mathrm{gC}}{\mathrm{mgN}}
$$

\section{Temperature effects on kinetic reaction rates}

All rates depend exponentially on temperature. The temperature effect for all first-order reactions used in the model is represented by:

$$
k(T)=k(20) \theta^{T-20}
$$

where:

$k(T)=$ reaction rate at temperature $\mathrm{T}^{\circ} \mathrm{C}\left[\mathrm{T}^{-1}\right]$

$k(20)=$ reaction rate at temperature $20^{\circ} \mathrm{C}^{\left.-\mathrm{T}^{-1}\right]}$

$\theta=$ temperature coefficient for the reaction. 


\section{Water Quality Kinetic Reaction Equations}

Well-developed models and tools are available to address the physical transport components of equations in water quality modeling. Particularly, 1D, 2D, and, increasingly, 3D hydrodynamic models are available to determine the velocity field and are becoming more practical with advancements in computer technology. Therefore, future water quality modeling developments will refine the description of kinetic processes in Equations 1 and 2. Kinetic processes describe changes in the constituent concentrations that are due to biological, chemical, biochemical, and physical processes. The historical development of oxygen, nitrogen, phosphorus, and carbon water quality models shows step-by-step extensions and increasing complexity.

This chapter describes governing equations for the current in-stream water quality module, which includes the major processes for nitrogen, phosphorus, carbon, and oxygen cycling. The water quality processes were simplified on the basis of selecting the dominant biochemical processes under consideration. Only process descriptions applicable to small streams are being incorporated into NSM. Hydrolysis of particulate organic nutrients into dissolved organic form is modeled as a first-order, temperature-dependent process. Mineralization of the organic nutrient pools back to inorganic nutrients (i.e. dissolved inorganic ammonium, phosphorus, carbon) is also modeled as a first-order, temperaturedependent process. The terms for mortality and excretion are modeled in the usual manner as first order losses with an identical temperature dependence for growth. Nitrification and denitrification influence the dissolved inorganic nitrogen fraction, which includes $\mathrm{NH}_{4}^{+}$and $\mathrm{NO}_{3}^{-}$as state variables. These processes are represented as first order, oxygendependent reactions. The NSM in-stream water quality module incorporates 12 state variables (Table 2). 
Table 2. In-stream water quality state variables

\begin{tabular}{|l|l|l|}
\hline Variable & Symbol & Notes \\
\hline Nitrate Nitrogen & $\mathrm{NO}_{3}^{-}$ & \\
\hline Ammonium Nitrogen & $\mathrm{NH}_{4}^{+}$ & \\
\hline Dissolved Organic Nitrogen & $\mathrm{DON}$ & \\
\hline Particulate Organic Nitrogen & $P O N$ & \\
\hline Dissolved Inorganic Phosphorus & $D I P$ & \\
\hline Dissolved Organic Phosphorus & $D O P$ & \\
\hline Particulate Organic Phosphorus & $P O P$ & \\
\hline Dissolved Inorganic Carbon & $D I C$ & \\
\hline Dissolved Organic Carbon & $D O C$ & \\
\hline Particulate Organic Carbon & $P O C$ & \\
\hline Dissolved Oxygen & $D O$ & \\
\hline Algae 1 & $A_{p 1}$ & Phytoplankton \\
\hline Algae 2 & $A_{p 2}$ & Phytoplankton \\
\hline Algae 3 & $A_{b 1}$ & Bottom algae \\
\hline Algae 4 & $A_{b 2}$ & Bottom algae \\
\hline
\end{tabular}

These model state variables can be used to compute the following composite variables:

- Total Nitrogen (TN)

- Total Kjeldahl Nitrogen (TKN)

- Total Phosphorus (TP)

- Total Organic Carbon (TOC)

- Ultimate Carbonaceous BOD (CBOD)

TN (TP) is a measure of all forms of dissolved and particulate nitrogen (phosphorus) present in waters. TOC is a measure of all the various forms of organic $\mathrm{C}$ found in waters. Ultimate $\mathrm{CBOD}$ reflects oxidation of both dissolved and particulate organic carbon.

$$
\begin{gathered}
\mathrm{TN}=\mathrm{NO}_{3}^{-}+\mathrm{NH}_{4}^{+}+\mathrm{PNH}_{4}^{+}+\mathrm{DON}+\mathrm{PON} \\
\mathrm{TKN}=\mathrm{NH}_{4}^{+}+\mathrm{PNH}_{4}^{+}+\mathrm{DON}+\mathrm{PON}
\end{gathered}
$$




$$
\begin{gathered}
T P=D I P+P I P+D O P+P O P \\
T O C=D O C+P O C \\
C B O D=r_{o c} D O C+r_{o c} P O C
\end{gathered}
$$

The transport of NSM state variables with their kinetic reaction rates expressed in source and sink terms is described in the following sections. Additional state variables such as benthic algae, zooplankton, and temperature will be added in the future versions of NSM.

\section{Nitrogen}

Nitrogen is transported into stream systems from airborne, land surface, underground, and in situ sources. Much of the nitrogen entering streams is transported with eroded sediments and solid organic matter (SOM), and dissolved form in surface runoff. The nitrogen forms commonly found in river water are: $\mathrm{NO}_{3}^{-}, \mathrm{NO}_{2}^{-}, \mathrm{NH}_{4}^{+}, \mathrm{DON}$, and PON (Meybeck 1982). These forms are reactive in the framework of the $\mathrm{N}$ cycle. The nitrogen cycle includes the additional processes of denitrification, nitrification, and $\mathrm{N}_{2}$ fixation that are not in the carbon and phosphorus cycles. $\mathrm{NO}_{2}^{-}$ concentrations are not tracked by the model because the amount of $\mathrm{NO}_{2}^{-}$present in the stream is usually very small relative to $\mathrm{NO}_{3}^{-}$. The instream nitrogen cycle simulated in NSM is illustrated in Figure 1.

The major processes involved in nitrogen transformations in the sediments and water column are:

- Mineralization of DON to $\mathrm{NH}_{4}^{+}$

- Nitrification of $\mathrm{NH}_{4}^{+}$to $\mathrm{NO}_{3}^{-}$

- Denitrification of $\mathrm{NO}_{3}^{-}$

- Biological uptake of $\mathrm{NH}_{4}^{+}$and $\mathrm{NO}_{3}^{-}$by phytoplankton and algae

- Biological respiration of $\mathrm{NH}_{4}^{+}$by phytoplankton and algae

- Dissolved sediment fluxes of $\mathrm{NH}_{4}^{+}, \mathrm{NO}_{3}^{-}$, and DON

- Adsorption/desorption of $\mathrm{NH}_{4}^{+}$onto suspended sediments

- Hydrolysis of PON to DON

- Biological mortality and excretion into the DON and PON pools

- Settling/resuspension of PON and sediment attached inorganic nitrogen. 


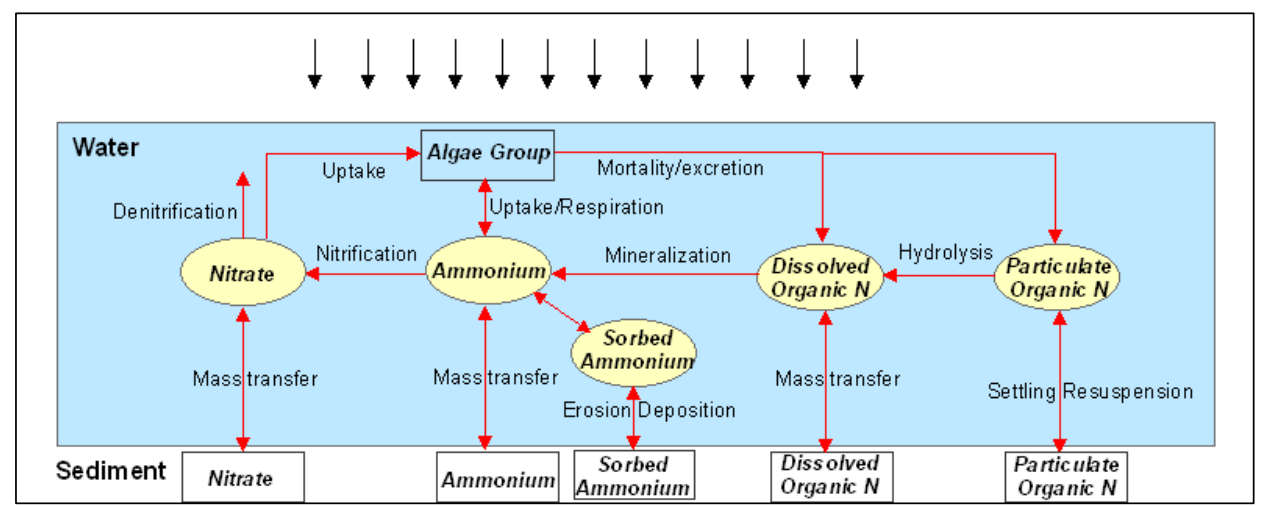

Figure 1. Simplified schematic representation of the in-stream nitrogen cycling processes

Four nitrogen variables are modeled: $\mathrm{PON}, \mathrm{DON}, \mathrm{NH}_{4}^{+}$, and $\mathrm{NO}_{3}^{-}$. Ammonium nitrogen is divided into particulate and dissolved concentrations by spatially variable dissolved fractions reflecting sorption.

The nitrogen equations in the water column and benthic sediment are summarized as follows:

\section{Water column}

$$
\begin{gathered}
\frac{\partial P O N_{c h}}{\partial t}=L\left(P O N_{c h}\right)+\frac{1}{h_{c h}}\left(v_{s} P O N_{c h}-v_{r} P O N_{s e d}\right) \\
+r_{n a} k_{d p} A_{p}+\frac{1}{h_{c h}} q_{0 N} k_{d b} A_{b}-k_{h n} P O N_{c h} \\
\frac{\partial D O N_{c h}}{\partial t}=L\left(D O N_{c h}\right)+\frac{k_{e}}{h_{c h}}\left(D O N_{s e d} / \varphi-D O N_{c h}\right) \\
+k_{h n} P O N_{c h}-F_{o x m n} k_{m n} D O N_{c h} \\
\frac{\partial T N H_{4 c h}^{+}=}{\partial t}+\frac{\left.T_{N} H_{4 c h}^{+}\right)+}{k_{e}}\left(f_{d 2} T N H_{4 s e d}^{+} / \varphi-f_{d} T N H_{4 c h}^{+}\right)+F_{o x m n} k_{m n} D O N_{c h} \\
-\frac{1}{h_{c h}}\left(\sum_{n=1}^{N} f_{p n} v_{s} T N H_{4 c h}^{+}-\sum_{n=1}^{N} f_{p 2 n} v_{r} T N H_{4 \text { sed }}^{+}\right) \\
+r_{n a} k_{r p} A_{p}-r_{n a} p_{a p} \mu_{p} A_{p}-\frac{1}{h_{c h}} p_{a b} \mu_{b N} A_{b}-F_{o x n a} k_{n i t} f_{d} T N H_{4 c h}^{+}
\end{gathered}
$$




$$
\begin{aligned}
\frac{\partial N O_{3 c h}^{-}}{\partial t}= & L\left(N O_{3 c h}^{-}\right)+\frac{k_{e}}{h_{c h}}\left(N O_{3 \text { sed }}^{-} / \varphi-N O_{3 c h}^{-}\right)+F_{o x n a} k_{n i t} f_{d} T N H_{4 c h}^{+} \\
& -\left(1-F_{o x d n}\right) \frac{D O C_{c h}}{K_{s c d n}+D O C_{s e d}} k_{d n i t} N O_{3 c h}^{-}-r_{n a}\left(1-P_{a p}\right) \mu_{p} A_{p} \\
& -\frac{1}{h_{c h}}\left(1-P_{a b}\right) \mu_{b N} A_{b}
\end{aligned}
$$

\section{Benthic sediment}

$$
\begin{aligned}
& \frac{\partial P O N_{s e d}}{\partial t}=\frac{1}{h_{\text {sed }}}\left(v_{s} P O N_{c h}-v_{r} P O N_{s e d}\right)-k_{h n} P O N_{s e d} \\
& \frac{\partial D O N_{s e d}}{\partial t}=\frac{k_{e}}{h_{\text {sed }}}\left(D O N_{c h}-D O N_{\text {sed }} / \varphi\right)+k_{h n} P O N_{\text {sed }}-F_{\text {oxmn }} k_{m n} D O N_{\text {sed }}
\end{aligned}
$$

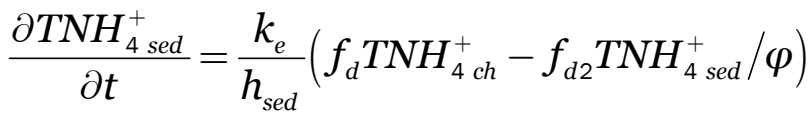

$$
\begin{aligned}
& +F_{\text {oxmn }} k_{m n} D O N_{\text {sed }}-F_{\text {oxna }} k_{\text {nit }} f_{d 2} \mathrm{TNH}_{4 \text { sed }}^{+} \\
& +\frac{1}{h_{\text {sed }}}\left(\sum_{n=1}^{N} f_{p n} v_{s n} \mathrm{TNH}_{4 \mathrm{ch}}^{+}-\sum_{n=1}^{N} f_{p 2 n} v_{r n} \mathrm{TNH}_{4 \text { sed }}^{+}\right) \\
& \frac{\partial \mathrm{NO}_{3 \text { sed }}^{-}}{\partial t}=\frac{k_{e}}{h_{\text {sed }}}\left(N O_{3 \text { ch }}^{-}-\frac{N O_{3 \text { sed }}^{-}}{\varphi}\right)+F_{\text {oxna }} k_{\text {nit }} f_{d 2} \mathrm{TNH}_{4 \text { sed }}^{+} \\
& -\left(1-F_{o x d n}\right) \frac{D O C_{s e d}}{K_{s c d n}+D O C_{s e d}} k_{d n i t} N O_{3 \text { sed }}^{-}
\end{aligned}
$$

where:

$P O N_{c h}=$ concentration of in-stream PON [M/L3]

$v_{s}=$ particle settling rate $[\mathrm{L} / \mathrm{T}]$

$v_{r}=$ particle resuspension rate $[\mathrm{L} / \mathrm{T}]$

$k_{d p}=$ temperature-dependent phytoplankton death rate $\left[\mathrm{T}^{-1}\right]$

$k_{d b}=$ temperature-dependent bottom algae death rate [ $\left.\mathrm{T}^{-1}\right]$

$A_{p}=$ stream phytoplankton concentration [M/L3]

$A_{b}=$ stream bottom algae concentration $\left[\mathrm{M} / \mathrm{L}^{2}\right]$

$B A=$ stream bottom surface area $\left[\mathrm{L}^{2}\right]$

$k_{h n}=$ temperature-dependent PON hydrolysis rate coefficient $\left[\mathrm{T}^{-1}\right]$ 


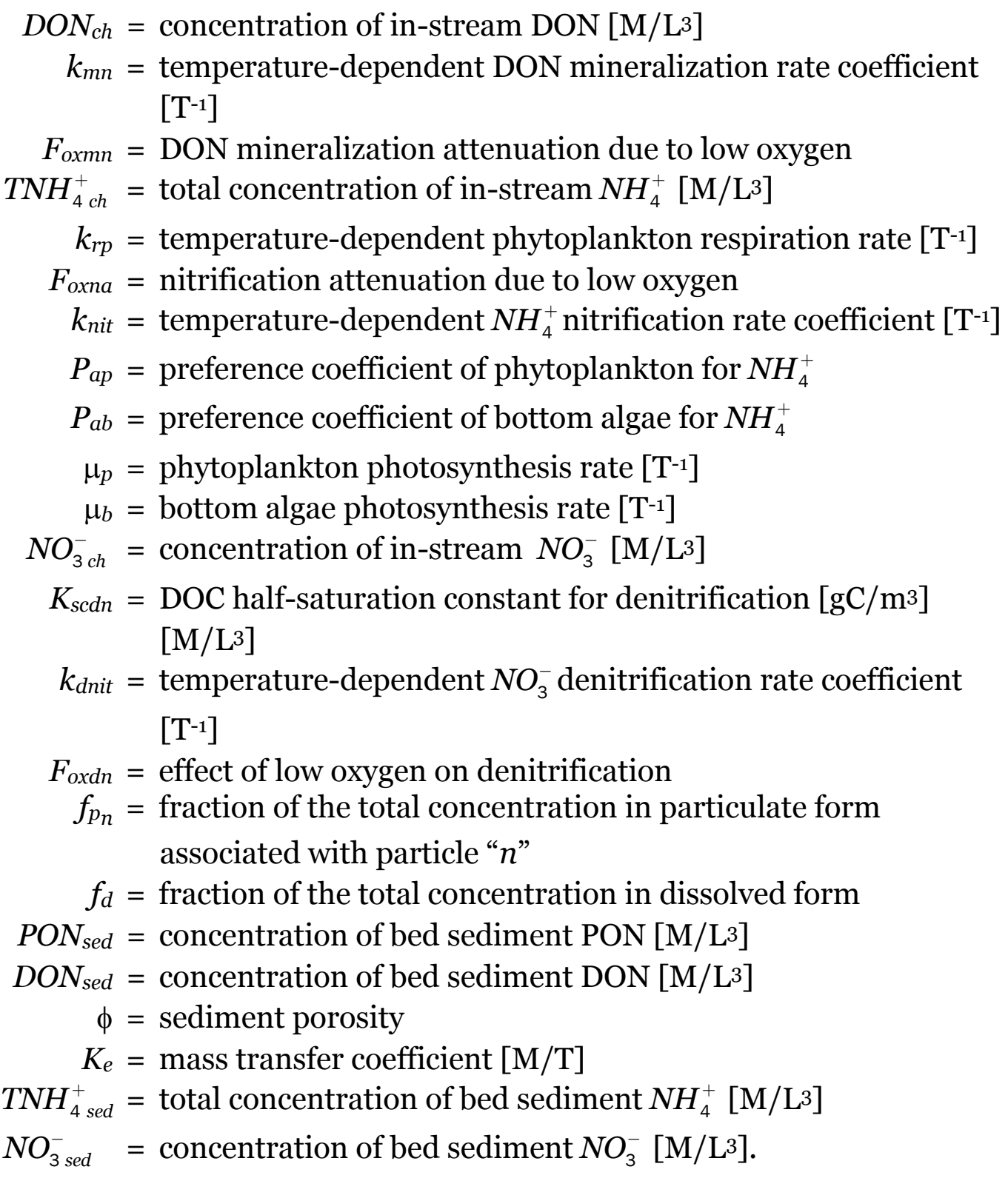

\section{Phosphorus}

Phosphorus is an important element because it is usually in short supply relative to other macronutrients (Correll 1998; Carpenter et al. 1998). In contrast to nitrogen and carbon, there is no gaseous atmospheric source. Phosphorus enters rivers primarily as particulate matter and secondarily as DIP also known as "ortho-P" $\left(\mathrm{H}_{3} \mathrm{PO}_{4}\right.$ and conjugate base forms). The phosphorus forms simulated in NSM are DIP, DOP, and POP. The instream phosphorus cycle simulated in NSM is illustrated in Figure 2. 
The major processes involved in phosphorus transformations in the sediments and water column are:

- Mineralization of DOP to DIP

- Biological uptake and respiration of DIP by phytoplankton and algae

- Dissolved sediment fluxes of DIP and DOP

- Adsorption/desorption of DIP onto suspended sediments

- Hydrolysis of POP to DOP

- Biological mortality and excretion into the DOP and POP pools

- Settling/resuspension of POP and PIP.

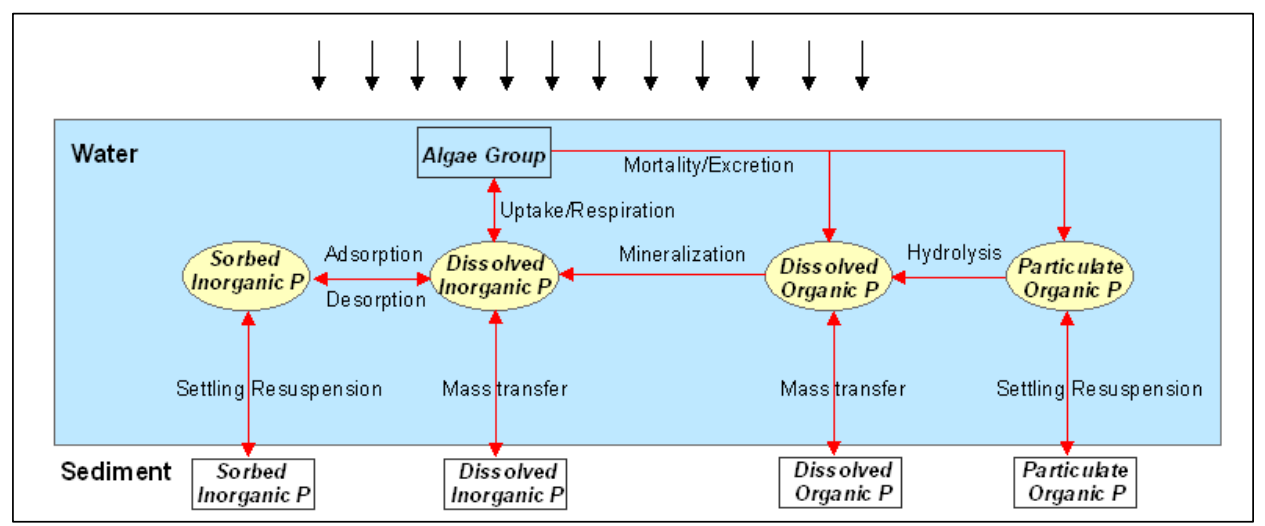

Figure 2. Simplified schematic representation of the in-stream phosphorus cycling processes

Three phosphorus variables are modeled: POP, DOP, and inorganic phosphorus. Inorganic phosphorus is divided into particulate and dissolved concentrations by spatially variable dissolved fractions. Dissolved or available inorganic phosphorus (DIP) interacts with particulate inorganic phosphorus (PIP) via a sorption-desorption mechanism.

The phosphorus equations in the water column and benthic sediment are summarized as follows:

Water column

$$
\begin{aligned}
\frac{\partial P O P_{c h}}{\partial t}= & L\left(P O P_{c h}\right)+\frac{1}{h_{c h}}\left(v_{s} P O P_{c h}-v_{r} P O P_{s e d}\right) \\
& +r_{p a} k_{d p} A_{p}+\frac{1}{h_{c h}} q_{O P} k_{d b} A_{b}-k_{h n} P O P_{c h}
\end{aligned}
$$




$$
\begin{aligned}
\frac{\partial D O P_{c h}}{\partial t}= & L\left(D O P_{c h}\right)+\frac{k_{e}}{h_{c h}}\left(D O P_{s e d} / \varphi-D O P_{c h}\right) \\
& +k_{h p} P O P_{c h}-F_{o x m p} k_{m p} D O P_{c h} \\
\frac{\partial T I P_{c h}}{\partial t}= & L\left(T I P_{c h}\right)+\frac{k_{e}}{h_{c h}}\left(f_{d 2} T I P_{s e d} / \varphi-f_{d} T I P_{c h}\right) \\
& -\frac{1}{h_{c h}}\left(\sum_{n=1}^{N} f_{p n} v_{s} T I P_{c h}-\sum_{n=1}^{N} f_{p 2 n} v_{r} T I P_{s e d}\right) \\
& +F_{\text {oxmp }} k_{m p} D O P_{c h}+r_{p a} k_{r p} A_{p}-r_{p a} \mu_{p} A_{p}-\frac{1}{h_{c h}} \mu_{b P} A_{b}
\end{aligned}
$$

\section{Benthic sediment}

$$
\begin{gathered}
\frac{\partial P O P_{\text {sed }}}{\partial t}=\frac{1}{h_{\text {sed }}}\left(v_{s} P O P_{c h}-v_{r} P O P_{\text {sed }}\right)-k_{h p} P O P_{\text {sed }} \\
\frac{\partial D O P_{\text {sed }}}{\partial t}=\frac{k_{e}}{h_{\text {sed }}}\left(D O P_{c h}-D O P_{\text {sed }} / \varphi\right)+k_{h p} P O P_{\text {sed }}-F_{\text {oxmp }} k_{m p} D O P_{\text {sed }} \\
\frac{\partial T I P_{\text {sed }}}{\partial t}=\frac{k_{e}}{h_{\text {sed }}}\left(f_{d} T I P_{c h}-f_{d 2} T I P_{\text {sed }} / \varphi\right)+\frac{1}{h_{\text {sed }}}\left(\sum_{n=1}^{N} f_{p n} v_{s} T I P_{c h}-\sum_{n=1}^{N} f_{p 2 n} v_{r} T I P_{\text {sed }}\right) \\
+F_{\text {oxmp }} k_{m p} D O P_{\text {sed }}
\end{gathered}
$$

where:

$P O P_{c h}=$ concentration of in-stream POP $\left[\mathrm{M} / \mathrm{L}^{3}\right]$

$D O P_{c h}=$ concentration of in-stream DOP [M/L3]

$T I P_{c h}=$ total concentration of in-stream inorganic $\mathrm{P}\left[\mathrm{M} / \mathrm{L}^{3}\right]$

$P O P_{\text {sed }}=$ concentration of bed sediment $\mathrm{POP}\left[\mathrm{M} / \mathrm{L}^{3}\right]$

$D O P_{\text {sed }}=$ concentration of bed sediment DOP $[\mathrm{M} / \mathrm{L} 3]$

$T I P_{\text {sed }}=$ total concentration of bed sediment inorganic $\mathrm{P}\left[\mathrm{M} / \mathrm{L}^{3}\right]$

$k_{h p}=$ temperature-dependent POP hydrolysis rate coefficient [ $\left.\mathrm{T}^{-1}\right]$

$k_{m p}=$ temperature-dependent DOP mineralization rate coefficient $\left[\mathrm{T}^{-1}\right.$ ]

$F_{\text {oxmp }}=$ DOP mineralization attenuation due to low oxygen

$f_{d 2}=$ fraction of total concentration in the dissolved phase

$f_{p 2 n}=$ fraction of total concentration in the particulate phase associated with size fraction. 


\section{Carbon}

The carbon constituents taken into account are: particulate organic carbon (POC), dissolved/colloidal organic carbon (DOC), and dissolved inorganic carbon (DIC). DOC in streams is usually comprised of minor amounts of biodegradable plant, phytoplankton and bacterial residues, which are being rapidly recycled, and major amounts of biological refractory residues comprised of substituted aromatic structures, and branched and partially oxidized cyclic aliphatic structures. The DIC actually consists of several carbonate constituents: carbon dioxide $\left(\mathrm{CO}_{2}\right)$, bicarbonate $\left(\mathrm{HCO}_{3}{ }^{-}\right)$, and carbonate $\left(\mathrm{CO}_{3}{ }^{2-}\right)$. The value of water $\mathrm{pH}$ is controlled by the carbonate system. Within the stream POC is not inert but readily transformed into DIC either directly or via DOC as an intermediate step. In-stream DOC is produced by incomplete hydrolysis of POC or by desorption from mineral surfaces. DOC contributes to the turbidity of surface waters, provides an energy source for organisms, and affects the fate and bioavailability of contaminants. Hydrophobic chemicals and some metals have high binding affinities for DOC. The dynamics of these toxics is intimately connected with the generation, transport, and fate of organic carbon. Nitrogen and phosphorus are contained as nutrients within DOC. The DIC balance additionally includes atmospheric fluxes of $\mathrm{CO}_{2}$ that are based on the difference between the atmospheric and water column values of $\mathrm{pCO}_{2}$ (vapor pressure of carbon dioxide). To estimate the $\mathrm{CO}_{2}$ fraction of the DIC pool, the carbonate buffer system, alkalinity, and $\mathrm{pH}$ that govern the subsequent partitioning of DIC between $\mathrm{pCO}_{2}$, bicarbonate, and carbonate ions need to be modeled. The gaseous and aqueous phase $\mathrm{CO}_{2}$ values are related by Henrys Law for calculation of $\mathrm{pCO}_{2}$. The in-stream carbon cycle simulated in NSM is illustrated in Figure 3.

The major processes involved in carbon transformations in the sediments and water column are:

- Atmospheric fluxes of DIC

- Mineralization of DOC to DIC

- Biological uptake and respiration of DIC by phytoplankton and algae

- Dissolved sediment fluxes of DIC and DOC

- Hydrolysis of POC to DOC

- Biological mortality and excretion into the DOC and POC pools

- Settling/resuspension of POC. 


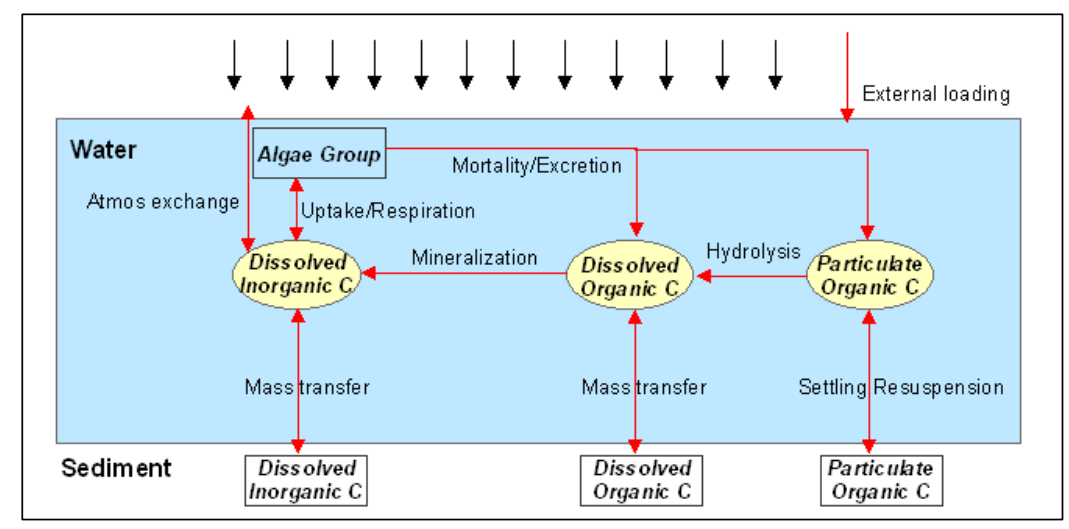

Figure 3. Simplified schematic representation of the in-stream carbon cycling processes

Three carbon variables are modeled: POC, DOC, and DIC. The carbon equations in the water column and benthic sediment are summarized as follows:

\section{Water column}

$$
\begin{aligned}
\frac{\partial P O C_{c h}}{\partial t}= & L\left(P O C_{c h}\right)-\frac{1}{h_{c h}}\left(v_{s} P O C_{c h}-v_{r} P O C_{s e d}\right) \\
& +r_{c a} k_{d p} A_{p}+\frac{1}{h_{c h}} r_{c a} k_{d b} A_{b}-k_{h c} P O C_{c h}
\end{aligned}
$$

$$
\begin{aligned}
\frac{\partial D O C_{c h}}{\partial t} & =L\left(D O C_{c h}\right)+\frac{k_{e}}{h_{c h}}\left(D O C_{s e d} / \varphi-D O C_{c h}\right)+k_{h c} P O C_{c h} \\
& -F_{o x m c} k_{m c} D O C_{c h}-r_{c n d n}\left(1-F_{o x d n}\right) \frac{D O C_{c h}}{K_{s c d n}+D O C_{c h}} k_{d n i t} f_{d} T N O_{3 c h}^{-}
\end{aligned}
$$

$$
\begin{aligned}
\frac{\partial D I C_{c h}}{\partial t}= & L\left(D I C_{c h}\right)+\frac{k_{e}}{h_{c h}}\left(D I C_{s e d} / \varphi-D I C_{c h}\right)+k_{a c}\left(k_{H} p_{C_{2}}-\alpha_{0} D I C_{c h}\right) \\
& +r_{c c o} F_{o x m c} k_{m c} D O C_{c h}+r_{c c a} k_{r p} A_{p}-r_{c c a} \mu_{p} A_{p} \\
& +\frac{1}{h_{c h}}\left(r_{c c a} k_{r b} A_{b}-r_{c c a} \mu_{b} A_{b}\right)
\end{aligned}
$$

\section{Benthic sediment}

$$
\frac{\partial P O C_{s e d}}{\partial t}=\frac{1}{h_{\text {sed }}}\left(v_{s} P O C_{c h}-v_{r} P O C_{s e d}\right)-k_{h c} P O C_{s e d}
$$




$$
\begin{aligned}
\frac{\partial D O C_{\text {sed }}}{\partial t}= & \frac{k_{e}}{h_{\text {sed }}}\left(D O C_{c h}-D O C_{\text {sed }} / \varphi\right)+k_{h c} P O C_{\text {sed }} \\
& -r_{\text {cndn }}\left(1-F_{\text {oxmc }}\right) \frac{D O C_{\text {sed }}}{K_{\text {scdn }}+D O C_{\text {sed }}} k_{m c} D O C_{\text {sed }} \\
\frac{\partial D I C_{\text {sed }}}{\partial t}= & \frac{k_{e}}{h_{\text {sed }}}\left(D I C_{c h}-D I C_{\text {sed }} / \varphi\right)+F_{\text {oxmc }} k_{m c} D O C_{c h}
\end{aligned}
$$

where:

$$
\begin{aligned}
P O C_{c h} & =\text { concentration of in-stream POC }\left[\mathrm{M} / \mathrm{L}^{3}\right] \\
D O C_{c h} & =\text { concentration of in-stream DOC }\left[\mathrm{M} / \mathrm{L}^{3}\right] \\
D I C_{c h} & =\text { concentration of in-stream DIC }(\mathrm{mole} / \mathrm{L})\left[\mathrm{M} / \mathrm{L}^{3}\right] \\
P O C_{\text {sed }} & =\text { concentration of bed sediment POC }\left[\mathrm{M} / \mathrm{L}^{3}\right] \\
D O C_{\text {sed }} & =\text { concentration of bed sediment DOC }\left[\mathrm{M} / \mathrm{L}^{3}\right] \\
D I C_{\text {sed }} & =\text { concentration of bed sediment } \mathrm{DIC}(\mathrm{mole} / \mathrm{L})\left[\mathrm{M} / \mathrm{L}^{3}\right] \\
k_{h c} & =\text { temperature-dependent POC hydrolysis rate coefficient }\left[\mathrm{T}^{-1}\right] \\
F_{\text {oxmc }} & =\text { DOC mineralization attenuation due to low oxygen } \\
k_{m c} & =\text { temperature-dependent DOC mineralization rate }\left[\mathrm{T}^{-1}\right] \\
k_{a c} & =\text { o.923 } k_{a}=\text { temperature-dependent } \mathrm{CO}_{2} \text { reaeration coefficient } \\
& {\left[\mathrm{T}^{-1}\right] } \\
k_{H}= & \text { Henry's constant }[\text { mole } /(\mathrm{L} \cdot \text { atm })] \\
p_{\mathrm{CO}_{2}} & =\text { partial pressure of carbon dioxide in the atmosphere }[\mathrm{atm}] \\
\alpha_{\mathrm{o}} & =\text { fraction of total inorganic carbon in carbon dioxide. }
\end{aligned}
$$

\section{Algae Group}

Algae are commonly included as state variables in water quality models because they impact DO and material cycling in water bodies and because excessive algae populations are of environmental concern. Phytoplankton and bottom algal communities are characterized as part of a physical, chemical, and biological assessment of water quality. Algae that are suspended or actively swimming in the water column are referred to as phytoplankton. The term "periphyton" is sometimes used to refer to benthic algae, while others use the term to refer to the entire attached community of microorganisms, including algae, bacteria, fungi, and protozoa. To avoid confusion within this section, "bottom algae" are used to designate the algal community attached to bottom rocks and stable sand surfaces. In many shallow streams and rivers, it is the attached algae (benthic algae, or periphyton, attached to submerged substrates) that are 
often of greater importance. These attached plants affect water quality in various ways, and their impact must often be considered in order to properly evaluate riverine water quality conditions.

NSM simulates algae that float in water bodies for phytoplankton. Algal involvement in the nutrient cycles is depicted schematically in the previous sections. Algae reduce the concentration of nutrients in the water by consuming phosphates, nitrate, and ammonium. Through assimilation these nutrients are transformed into organic materials which serve as a food source. A portion of the organic matter that is not used for food decomposes, which further affects the oxygen and nutrient levels in the water bodies. The activities of algae in turn are affected by the physical environment. Figure 4 provides an overview of algal kinetic processes simulated in NSM.

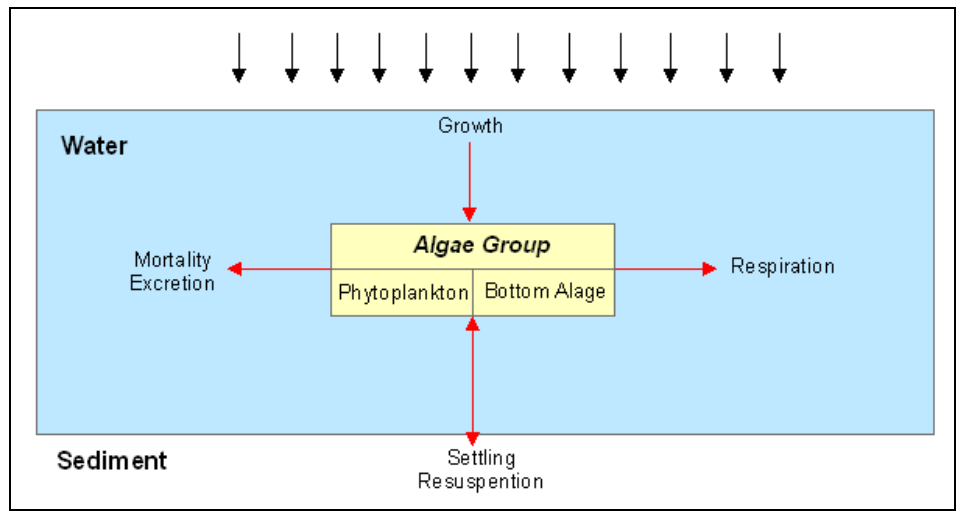

Figure 4. Simplified schematic representation of the in-stream algae kinetic processes

NSM simulates the growth and accumulation of two forms of bottom algae. The bottom algae algorithm includes algae biomass as a state variable and three multi-variate rate vectors: primary production, algal respiration, and the removal processes that result in export of biomass from the system.

Four algae groups are configurable within NSM. Algal biomass can be simulated either in units of chlorophyll-a ( $\mu \mathrm{g}$ Chla $\left.\mathrm{L}^{-1}\right)$ or carbon ( $\mathrm{mg} \mathrm{C} \mathrm{L} \mathrm{L}^{-1}$ ). Chlorophyll-a is most commonly available as an estimate of algal biomass. Algal biomass can be represented in the model either for the entire algae assemblage or as the individual contributions by certain groups, e.g., phytoplankton, benthos, and periphyton. 


\section{Phytoplankton}

The phytoplankton biomass increases due to photosynthesis and is lost via respiration, death, and settling. Through the process of photosynthesis, phytoplankton consume carbon dioxide and release oxygen back into the water body. At the same time algal respiration consumes oxygen and releases carbon dioxide.

NSM allows for the specification of two phytoplankton groups. Each is governed by the same mass balance equation. Distinctions between the groups are represented by using different parameter values. The algorithms for predicting variations in phytoplankton concentrations are based upon routines included in the QUAL2K model (Chapra et al. 2005). The kinetic equation for in-stream phytoplankton can be expressed as:

$$
\frac{d A_{p}}{d t}=-\frac{1}{h_{c h}}\left(v_{s} A_{p}-v_{r} A_{p s e d}\right)+\mu_{p} A_{p}-k_{r p} A_{p}-k_{d p} A_{p}
$$

Without interactions with the settled algae flux, the kinetic equation for instream phytoplankton can be reduced to:

$$
\frac{d A_{p}}{d t}=-\frac{1}{h_{c h}} v_{s} A_{p}+\mu_{p} A_{p}-k_{r p} A_{p}-k_{d p} A_{p}
$$

\section{Photosynthesis rate}

The photosynthetic process is important in producing oxygen. Nutrients tend to limit photosynthesis with phosphorus commonly the limiting nutrient due to its low mobility.

Phytoplankton photosynthesis is a function of temperature, nutrients, and light:

$$
\mu_{p}=k_{g p} \varphi_{N p} \varphi_{L p}
$$

where:

$\mu_{p}=$ phytoplankton photosynthesis rate $\left[\mathrm{T}^{-1}\right]$ 
$k_{g p}=$ maximum photosynthesis rate at temperature $T\left[\mathrm{~T}^{-1}\right]$

$\phi_{N p}=$ phytoplankton nutrient attenuation factor (between $\mathrm{o}$ and 1 )

$\phi_{L p}=$ phytoplankton light attenuation coefficient (between $\mathrm{O}$ and 1 ).

Nutrient limitation of the photosynthesis rate is dependent on nutrient concentration. Michaelis-Menten equations are used to represent growth limitation for inorganic $\mathrm{N}$ and $\mathrm{P}$. The minimum value is then used to compute the nutrient attenuation factor:

$$
\varphi_{N p}=\min \left(\frac{N H_{4 c h}^{+}+N O_{3 c h}^{-}}{K_{s N p}+N H_{4 c h}^{+}+N O_{3 c h}^{-}}, \frac{D I P_{c h}}{K_{s P p}+D I P_{c h}}, \frac{D I C_{c h}}{K_{s C p}+D I C_{c h}}\right)
$$

where:

$$
\begin{aligned}
& K_{S N p}=\mathrm{N} \text { half-saturation constant }[\mu \mathrm{g} \mathrm{N} / \mathrm{L}] \\
& K_{s P p}=\mathrm{P} \text { half-saturation constant }[\mu \mathrm{g} \mathrm{P} / \mathrm{L}] \\
& K_{s C p}=\text { inorganic C half-saturation constant [mole/L] }
\end{aligned}
$$

The effect of light on phytoplankton growth is complicated by the fact that several factors have to be integrated to come up with the total effect. It is assumed that light attenuation through the water follows the BeerLambert law

$$
I_{z}=0.47 I_{0} e^{-k_{e x z}}
$$

where:

$$
\begin{aligned}
I_{z}= & \text { photosynthetically available radiation }(\mathrm{PAR}) \text { at depth } z \text { below } \\
& \text { the water surface }[\mathrm{Ly} / \mathrm{d}] \\
k_{e x}= & \text { light extinction coefficient }\left[\mathrm{L}^{-1}\right] \\
I_{0}= & \text { light intensity at the water surface }\left[\mathrm{cal} / \mathrm{cm}^{2} / \mathrm{d}\right]
\end{aligned}
$$

Three models are used to characterize the impact of light on photosynthesis and compute the phytoplankton light attenuation coefficient (Table 3). 
Table 3. Phytoplankton light attenuation equations

\begin{tabular}{|l|l|l|l|}
\hline No. & Model & Equation & Reference \\
\hline 1 & Half-saturation model & $\varphi_{L p}=\frac{I_{0} e^{-k_{e x} z}}{K_{L p}+I_{0} e^{-k_{e x} z}}$ & Baly (1935) \\
\hline 2 & Smith's equation & $\varphi_{L p}=\frac{I_{0} e^{-k_{e x} z}}{\sqrt{K_{L p}^{2}+\left(I_{0} e^{-k_{e x} z}\right)^{2}}}$ & Smith (1936) \\
\hline 3 & Steele's equation & $\varphi_{L p}=\frac{I_{0} e^{-k_{e x} z}}{K_{L p}} \exp \left(1+\frac{I_{0} e^{-k_{e x} z}}{K_{L p}}\right)$ & Steele (1962) \\
\hline
\end{tabular}

where $K_{L p}$ is the appropriate phytoplankton light parameter for each light model.

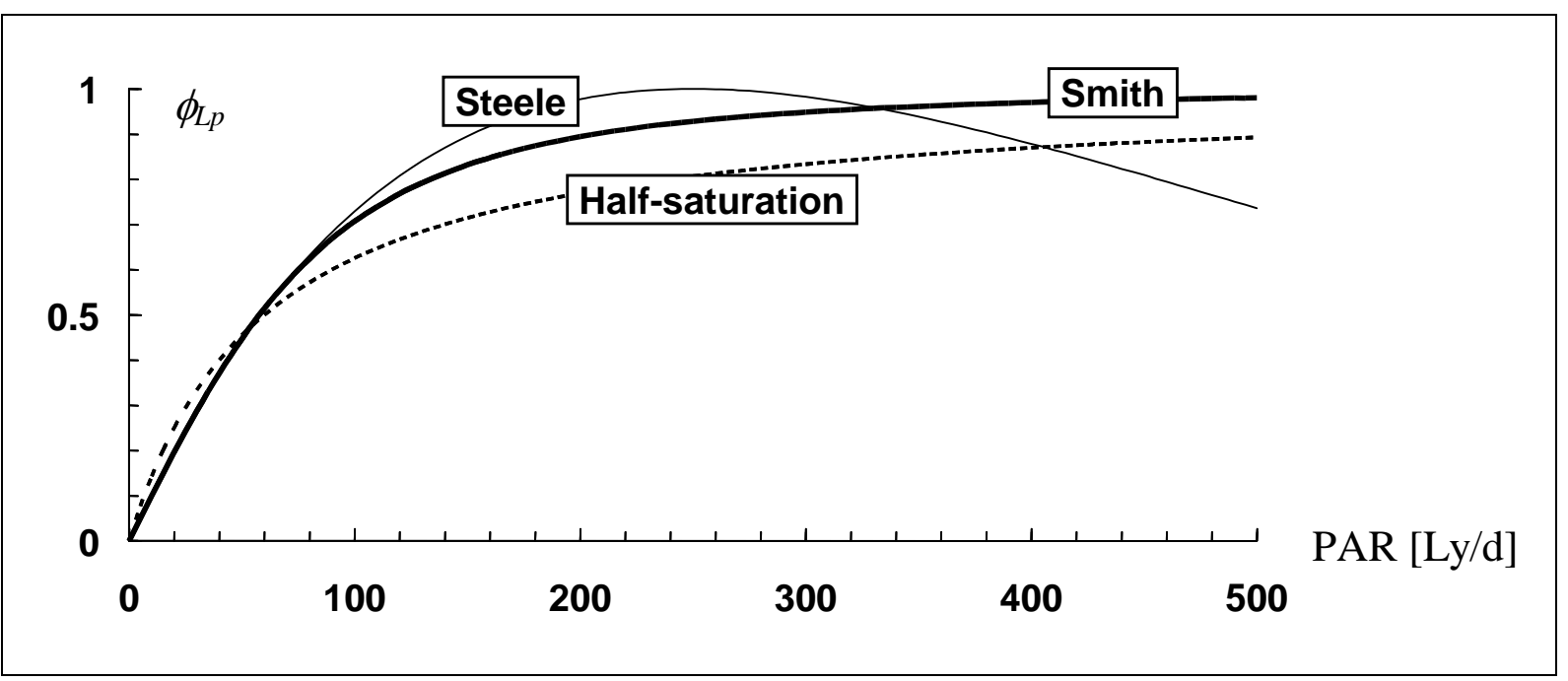

Figure 5. Three models used for phytoplankton photosynthetic light dependence

Preference coefficient for ammonium nitrogen

Nitrogen is essential to algae for assimilation of proteins and enzymes. Although phytoplankton take up and use both $\mathrm{NH}_{4}^{+}$and $\mathrm{NO}_{3}^{-}$, their preference for the former has been demonstrated for physiological reasons (Walsh and Dugdale 1972). The preference coefficient of phytoplankton for $\mathrm{NH}_{4}^{+}$as a nitrogen source is determined by: 


$$
\begin{aligned}
P_{a p}= & \frac{N H_{4 c h}^{+} N O_{3 c h}^{-}}{\left(k_{h n x p}+N H_{4 c h}^{+}\right)\left(k_{h n x p}+N O_{3 c h}^{-}\right)} \\
& +\frac{N H_{4 c h}^{+} k_{h n x p}}{\left(N H_{4 c h}^{+}+N O_{3 c h}^{-}\right)\left(k_{h n x p}+N O_{3 c h}^{-}\right)}
\end{aligned}
$$

where:

$$
k_{h n x p}=\text { preference coefficient of phytoplankton for } \mathrm{NH}_{4}^{+}\left[\mathrm{mg} \mathrm{N} / \mathrm{m}^{3}\right] \text {. }
$$

\section{Bottom algae}

As with phytoplankton, bottom algae growth is impacted by temperature, light, and nutrients. The growth of bottom algae consumes nutrients and produces oxygen. Bottom algae, like phytoplankton, also excrete cell contents and die, recycling dissolved and particulate organic matter to the stream's carbon and nutrient pools. While the modeling approaches used for phytoplankton and bottom algae are similar, bottom algae differ from phytoplankton in a number of fundamental ways:

- Bottom algae do not move with the water current, as do phytoplankton,

- Bottom algae typically dwell on or near the bottom, so are not impacted by the average light in the water column but the light reaching the bottom (substrate).

- Bottom algae are limited by the amount of substrate available for growth.

- There is typically a maximum density for attached plants.

Sources and sinks for bottom algae include growth, death, and respiration. Growth is computed from a maximum rate that is then modified based upon available light and internal nutrients. Unlike phytoplankton, bottom light rather than average water column light is used in the computation of growth. Rates of death and respiration are temperature dependent. Rates of growth, respiration, and death impact other model state variables including dissolved oxygen and nutrients.

The kinetic equation for in-stream bottom algae can be expressed as:

$$
\frac{d A_{b}}{d t}=\mu_{b} A_{b}-F_{o x b} k_{r b} A_{b}-k_{d b} A_{b}
$$


where:

$A_{b}=$ stream bottom algal concentration $\left[\mathrm{M} / \mathrm{L}^{2}\right]$

$\mu_{b}=$ benthic algal photosynthesis rate $\left[\mathrm{T}^{-1}\right]$

$F_{o x b}=$ attenuation due to low oxygen

$k_{r b}=$ temperature-dependent benthic algal respiration rate [ $\left.\mathrm{T}^{-1}\right]$

$k_{d b}=$ temperature-dependent benthic algal death rate $\left[\mathrm{T}^{-1}\right]$.

\section{Photosynthesis}

Bottom algal photosynthesis is a function of temperature, nutrients, and light:

$$
\mu_{b}=k_{g b} \varphi_{N b} \varphi_{L b}
$$

where:

$k_{g b}=$ maximum bottom algal rate at temperature $T\left[\mathrm{~T}^{-1}\right]$

$\phi_{N b}=$ bottom algal nutrient attenuation factor (between 0 and 1)

$\phi_{L b}=$ bottom algal light attenuation coefficient (between 0 and 1 ).

The effect of nutrient limitation on bottom plant photosynthesis is modeled in a different way than for the phytoplankton. Rather than being dependent on external nutrient concentration, the photosynthesis rate is dependent on intracellular nutrients using a formulation originally developed by Droop (1974)

$$
\varphi_{N b}=\min \left(1-\frac{q_{0 N}}{q_{N}}, 1-\frac{q_{0 P}}{q_{P}}, \frac{D I C_{c h}}{K_{s C_{b}}+D I C_{c h}}\right)
$$

where:

$$
\begin{aligned}
q_{N} \text { and } q_{P}= & \text { the cell quotas of nitrogen }\left[\mathrm{mgN} \mathrm{mgA}^{-1}\right] \text { and phosphorus } \\
& {\left[\mathrm{mgP} \mathrm{mgA}^{-1}\right], \text { respectively, } } \\
q_{\mathrm{oN}} \text { and } q_{\mathrm{o} P}= & \text { the minimum cell quotas of nitrogen }\left[\mathrm{mgN} \mathrm{mgA}^{-1}\right] \text { and } \\
& \text { phosphorus }\left[\mathrm{mgP} \mathrm{mgA}^{-1}\right], \text { respectively, and } \\
k_{\mathrm{s} C}= & \text { inorganic carbon half-saturation constant for the bottom } \\
& \text { algae [mole/L]. }
\end{aligned}
$$


The cell quotas represent the ratios of the intracellular nutrient to the bottom plant's weight. Their mass balance equations are described as follows.

$$
\begin{gathered}
q_{N}=\frac{I N_{b}}{A_{b}} \\
q_{N}=\frac{I P_{b}}{A_{b}}
\end{gathered}
$$

where:

$$
\begin{aligned}
& I N_{b}=\text { intracellular nitrogen concentration }\left[\mathrm{mgN} / \mathrm{m}^{2}\right] \\
& I P_{b}=\text { intracellular phosphorus concentration }\left[\mathrm{mgP} / \mathrm{m}^{2}\right] .
\end{aligned}
$$

The change in intracellular nitrogen and phosphorus in bottom algal cells is calculated from

$$
\begin{gathered}
\frac{d I N_{b}}{d t}=\mu_{b N} A_{b}-F_{o x b} k_{r b} A_{b}-k_{d b} A_{b} \\
\frac{d I P_{b}}{d t}=\mu_{b P} A_{b}-F_{o x b} k_{r b} A_{b}-k_{d b} A_{b} \\
\mu_{b N}=\rho_{m N} \frac{N H_{4 c h}^{+}+N O_{3 c h}^{-}}{k_{s N b}+N H_{4 c h}^{+}+N O_{3 c h}^{-}} \frac{N H_{4 c h}^{+} k_{h n x p}}{k_{q N}+\left(q_{N}+q_{0 N}\right)} \\
\mu_{b P}=\rho_{m P} \frac{D I P}{k_{s P b}+D I P} \frac{k_{q P}}{k_{q P}+\left(q_{P}+q_{o P}\right)}
\end{gathered}
$$

where:

$\rho_{m N}$ and $\rho_{m P}=$ the maximum uptake rates for nitrogen $[\mathrm{mgN} / \mathrm{mgA} / \mathrm{d}]$ and phosphorus $[\mathrm{mgP} / \mathrm{mgA} / \mathrm{d}]$, respectively, $k_{s N b}$ and $k_{s P b}=$ half-saturation constants for external nitrogen [ $\left.\mu \mathrm{gN} / \mathrm{L}\right]$ and phosphorus $[\mu \mathrm{gP} / \mathrm{L}]$, respectively, and $K_{q N}$ and $K_{q P}=$ half-saturation constants for intracellular nitrogen [mgN $\mathrm{mgA}^{-1}$ ] and phosphorus [mgP mgA ${ }^{-1}$, respectively. 
Light limitation is determined by the amount of photosynthetically active radiation (PAR) reaching the bottom of the water column. This quantity is computed with the Beer-Lambert law evaluated at the bottom of the river:

$$
I_{H}=I_{0} e^{-k_{e x} h_{c h}}
$$

where:

$I(H)$ is light intensity at depth $H$ below the water surface [Ly/d], $I(\mathrm{o})$ is light intensity just below the water surface $[\mathrm{Ly} / \mathrm{d}]$.

Three models are used to characterize the impact of light on bottom algae photosynthesis. Substituting the above formulation into these models yields the following formulas for the bottom algae light attenuation coefficient:

Table 4. Bottom algae light attenuation equations

\begin{tabular}{|l|l|l|}
\hline No. & Model & Equation \\
\hline 1 & Half-saturation model & $\varphi_{L b}=\frac{I_{0} e^{-k_{e x} h_{c h}}}{K_{L b}+I_{0} e^{-k_{e x} h_{c h}}}$ \\
\hline 2 & Smith's equation & $\varphi_{L b}=\frac{I_{0} e^{-k_{e x} h_{c h}}}{\sqrt{K_{L b}^{2}+\left(I_{0} e^{-k_{e x} h_{c h}}\right)^{2}}}$ \\
\hline 3 & Steele's equation & $\varphi_{L b}=\frac{I_{0} e^{-k_{e x} h_{c h}}}{K_{L b}} \exp \left(1+\frac{I_{0} e^{-k_{e x} h_{c h}}}{K_{L b}}\right)$ \\
\hline
\end{tabular}

where $K_{L b}$ is the appropriate bottom algae light parameter for each light model.

\section{Losses}

Bottom algal biomass decreases due to respiration and death. Bottom algal respiration is represented using first-order, temperature-corrected kinetics:

$$
k_{r b}=k_{r b}(20) \theta_{r b}^{T-20}
$$


where $k_{r b}(20)$ is the bottom algae respiration rate constant at $\left.20^{\circ} \mathrm{C}^{-1} \mathrm{~T}^{-1}\right]$ and $\theta_{r b}$ is the bottom algae respiration temperature coefficient.

Bottom algal death is also represented using first-order, temperaturecorrected kinetics:

$$
k_{d b}=k_{d b}(20) \theta_{d b}^{T-20}
$$

where $k_{d b}(20)$ is the bottom algae death rate constant at $20^{\circ} \mathrm{C}\left[\mathrm{T}^{-1}\right]$ and $\theta_{d b}$ is the bottom algae death temperature coefficient.

The preference coefficient of bottom algae for $\mathrm{NH}_{4}^{+}$as a nitrogen source is determined by:

$$
\begin{aligned}
P_{a b}= & \frac{N H_{4 c h}^{+} N O_{3 c h}^{-}}{\left(k_{h n x b}+N H_{4 c h}^{+}\right)\left(k_{h n x b}+N O_{3 c h}^{-}\right)} \\
& +\frac{N H_{4 c h}^{+} k_{h n x b}}{\left(N H_{4 c h}^{+}+N O_{3 c h}^{-}\right)\left(k_{h n x b}+N O_{3 c h}^{-}\right)}
\end{aligned}
$$

where:

$$
k_{h n x b}=\text { preference coefficient of bottom algae for } \mathrm{NH}_{4}^{+}\left[\mathrm{mg} \mathrm{N} / \mathrm{m}^{3}\right] \text {. }
$$

\section{Dissolved Oxygen}

The final in-stream cycle that will be discussed is the DO balance. An adequate DO concentration is a basic requirement for a healthy aquatic ecosystem. DO concentration is generally viewed as an indicator of the overall well-being of streams and their associated ecosystems. DO dynamics include atmospheric exchange, the sediment oxygen demand (SOD), microbial use during organic matter mineralization and nitrification, photosynthetic oxygen production and respiratory oxygen consumption, and respiration by other optional biotic components. The major processes involved in modeling DO are shown in Figure 6.

The following processes are considered in computing DO:

- Exchange to and from the air/water interface

- Utilization of oxygen at the sediment/water interface (i.e. SOD) 
- Utilization of oxygen as bacteria degrade organic matter

- Utilization of oxygen in the process of nitrification

- Photosynthetic oxygen production and respiratory consumption by phytoplankton and algae.

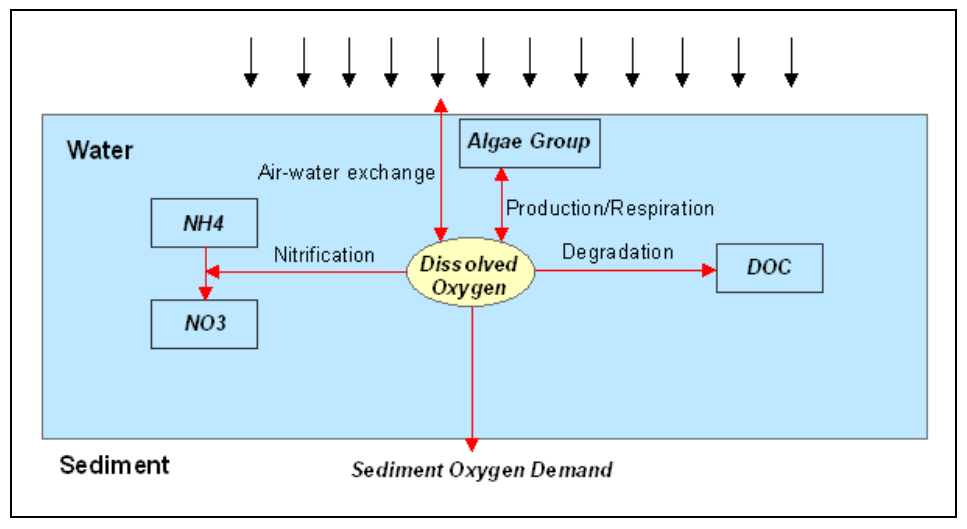

Figure 6. Simplified schematic representation of the in-stream DO dynamic processes

Sources of DO include algal photosynthesis and atmospheric reaeration. DO is lost through algal respiration, nitrification, and breakdown of organic carbon (in particular, DOC), and bottom sediments. Five state variables are included in the DO balance: ammonium, nitrate, DOC, phytoplankton, and DO. All constituents exerting an oxygen demand must be included in the DO kinetic equation.

The kinetic rate equation for in-stream DO concentration is:

$$
\begin{aligned}
\frac{d D O_{c h}}{d t}= & k_{a}\left(D O_{s}-D O_{c h}\right)+r_{o a}\left(r_{o c a} P_{a p}+r_{o c n}\left(1-P_{a p}\right)\right) \mu_{p} A_{p}-r_{o a} r_{o c a} k_{r p} A_{p} \\
& +\frac{1}{h_{c h}}\left(r_{o a} \mu_{b} A_{b}-r_{o a} k_{r b} A_{b}\right)-r_{o n} F_{o x n a} k_{n i t} f_{d} T N H_{4 c h}^{+}-r_{o c a} F_{o x m c} k_{m c} D O C_{c h}-S_{S O D}
\end{aligned}
$$

where:

$$
\begin{aligned}
D O_{c h} & =\text { concentration of in-stream } \mathrm{DO}[\mathrm{M} / \mathrm{L} 3] \\
k_{a} & =\text { temperature-dependent oxygen reaeration coefficient }\left[\mathrm{T}^{-1}\right] \\
D O_{s} & =\text { saturation concentration of oxygen }\left[\mathrm{mgO}_{2} / \mathrm{L}\right] \\
S_{S O D} & =\text { sediment oxygen demand rate }\left[\mathrm{M} / \mathrm{L}^{3}\right] .
\end{aligned}
$$




\section{Oxygen reaeration coefficient}

Oxygen-deficient (i.e. below saturation) waters are replenished via atmospheric reaeration. The reaeration coefficient is computed as a function of the stream's hydraulics and (optionally) wind velocity:

$$
k_{a}=k_{a h}+\frac{K_{a w}}{h_{c h}}
$$

where:

$$
\begin{aligned}
k_{a h}= & \text { reaeration rate based on the stream's hydraulic characteristics } \\
& {\left[\mathrm{T}^{-1}\right] } \\
K_{a w}= & \text { reaeration mass-transfer coefficient based on wind velocity } \\
& {[\mathrm{L} / \mathrm{T}] . }
\end{aligned}
$$

Various methods have been used to calculate atmospheric reaeration coefficients and experience has shown that the most effective method depends upon the prevalent hydraulic characteristics of the system. Each method corresponds to an empirical formula, which has proven accurate for a particular set of hydraulic conditions.

The hydraulic reaeration equations pertaining to rivers are shown in Table 5 .

The wind effect reaeration equations are listed in Table 6. 
Table 5. Hydraulic reaeration equations

\begin{tabular}{|c|c|c|c|}
\hline No. & Equation & Applicability & Reference \\
\hline 1 & $\begin{array}{l}k_{a h}=3.93 \frac{u^{0.5}}{h^{1.5}} \\
u=\text { mean water velocity }[\mathrm{m} / \mathrm{s}] \\
h=\text { mean water depth }[\mathrm{m}]\end{array}$ & $\begin{array}{l}\text { depths between } \\
1-30 \mathrm{ft} \text { and } \\
\text { velocities } \\
\text { between } 0.5-1.6 \\
\text { fps }\end{array}$ & $\begin{array}{l}\text { O'Connor and } \\
\text { Dobbins (1958) }\end{array}$ \\
\hline 2 & $k_{a h}=5.026 \frac{u}{h^{1.67}}$ & $\begin{array}{l}\text { depths between } \\
2-11 \mathrm{ft} \text { and } \\
\text { velocities } \\
\text { between 1.8-5 fps }\end{array}$ & $\begin{array}{l}\text { Churchill et al. } \\
\text { (1962) }\end{array}$ \\
\hline 3 & $k_{a h}=5.32 \frac{u^{0.67}}{h^{1.85}}$ & $\begin{array}{l}\text { depths between } \\
0.4-2.4 \mathrm{ft} \text { and } \\
\text { velocities between } \\
0.1-1.8 \mathrm{fps}\end{array}$ & $\begin{array}{l}\text { Owens et al. } \\
(1964)\end{array}$ \\
\hline 4 & $\begin{array}{l}k_{a h}=88(u \cdot s)^{0.313} h^{-0.353} \\
\text { for } Q<0.556 \mathrm{cms}(<19.64 \mathrm{cfs}) \\
k_{a h}=142(u \cdot s)^{0.333} h^{-0.66} B_{t}^{-0.243} \\
\text { for } Q>0.556 \mathrm{cms}(>19.64 \mathrm{cfs})\end{array}$ & $\begin{array}{l}\text { for channel control } \\
\text { streams }\end{array}$ & $\begin{array}{l}\text { Melching and } \\
\text { Flores (1999) }\end{array}$ \\
\hline 5 & $\begin{array}{l}k_{a h}=2.16\left(1+9 F_{d}^{0.25}\right) \frac{u_{*}}{h_{c h}} \\
u_{*}=\sqrt{g R_{h} s} \text { is shear velocity [m/s] } \\
F_{d}=u / \sqrt{g h_{d}} \text { is Froude number } \\
R_{h}=\text { hydraulic radius [m] } \\
s=\text { channel slope } \\
h_{d}=\text { the hydraulic depth }[\mathrm{m}] \\
B_{t}=\text { top width of the channel }[\mathrm{m}]\end{array}$ & & $\begin{array}{l}\text { Thackston and } \\
\text { Dawson (2001) }\end{array}$ \\
\hline
\end{tabular}

Table 6. Wind effect reaeration equations

\begin{tabular}{|l|l|l|}
\hline No. & Equation & Reference \\
\hline 1 & $\begin{array}{l}K_{a w}=0.728 u_{w, 10}^{0.5}-0.317 u_{w, 10}+0.0372 u_{w, 10}^{2} \\
u_{w, 10}=\text { wind speed measured } 10 \text { meters above the water } \\
\text { surface }[\mathrm{m} / \mathrm{s}]\end{array}$ & Banks and Herrera (1977) \\
\hline 2 & $K_{a w}=0.0986 u_{w, 10}^{1.64}$ & Wanninkhof et al. (1991) \\
\hline
\end{tabular}

\section{Oxygen attenuation coefficient}

For an individual nutrient, two equations are used to represent the oxygen attenuation of the oxidation rate: 
Saturating exponential

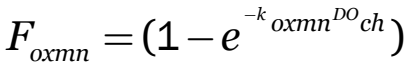

$$
\begin{aligned}
& F_{\text {oxna }}=\left(1-e^{-k} \text { oxna }{ }^{D O} c h\right) \\
& F_{o x d n}=\left(1-e^{-k} \operatorname{oxdn}^{D O} c h\right) \\
& F_{\text {oxmp }}=\left(1-e^{-k} \text { oxmp } p^{D O} c h\right) \\
& F_{\text {oxmc }}=\left(1-e^{-k o x m c^{D O} c h}\right)
\end{aligned}
$$

Half-saturation

$$
\begin{aligned}
& F_{\text {oxmn }}=D O_{c h} /\left(K_{\text {oxmn }}+D O_{c h}\right) \\
& F_{\text {oxna }}=D O_{c h} /\left(K_{\text {oxna }}+D O_{c h}\right) \\
& F_{\text {oxdn }}=D O_{c h} /\left(K_{\text {oxdn }}+D O_{c h}\right) \\
& F_{\text {oxmp }}=D O_{c h} /\left(K_{o x m p}+D O_{c h}\right) \\
& F_{\text {oxmc }}=D O_{c h} /\left(K_{o x m c}+D O_{c h}\right)
\end{aligned}
$$

where

$k_{\text {oxmn }}=$ exponential coefficient for DON mineralization $\left[\mathrm{L} / \mathrm{mgO}_{2}\right]$

$k_{\text {sxna }}=$ exponential coefficient for nitrification $\left[\mathrm{L} / \mathrm{mgO}_{2}\right]$

$k_{o x d n}=$ exponential coefficient for denitrification $\left[\mathrm{L} / \mathrm{mgO}_{2}\right]$

$k_{\text {oxmn }}=$ exponential coefficient for DON mineralization $\left[\mathrm{L} / \mathrm{mgO}_{2}\right]$

$k_{\text {oxmc }}=$ exponential coefficient for DOC mineralization $\left[\mathrm{L} / \mathrm{mgO}_{2}\right]$

$K_{\text {oxmn }}=$ DO half-saturation constant for DON mineralization $\left[\mathrm{mgO}_{2} / \mathrm{L}\right]$

$K_{\text {oxna }}=$ DO half-saturation constant for nitrification $\left[\mathrm{mgO}_{2} / \mathrm{L}\right]$

$K_{o x d n}=$ DO half-saturation constant for denitrification $\left[\mathrm{mgO}_{2} / \mathrm{L}\right]$

$K_{\text {oxmp }}=$ DO half-saturation constant for DOP mineralization $\left[\mathrm{mgO}_{2} / \mathrm{L}\right]$

$K_{\text {oxmc }}=$ DO half-saturation constant for DOC mineralization $\left[\mathrm{mgO}_{2} / \mathrm{L}\right]$. 


\section{Sediment oxygen demand}

Sediment oxygen demand (SOD) is a rate at which oxygen is consumed by sediments from the overlying water column. It is well known that SOD is the largest dissolved oxygen (DO) sink within natural waters. In addition to chemical and biological processes within the sediment (DiToro 2001), the rate of SOD also depends on the water velocity above the sediment/water interface (Boudreau and Joergensen 2001). Both theoretical (Nakamura and Stefan 1994) and experimental (House 2003) results have provided relationships that describe the effect of water velocity on SOD. In current NSM, SOD is modeled with a single parameter. This simplification will be updated in the future research.

Processes responsible for SOD are far too complex to be represented by a single parameter. In history, Fillos and Molof (1972) modeled the SOD with monod kinetics, in which SOD is limited by the DO in the water column. Walker and Snodgrass (1985) presented a slightly more complex SOD expression in which SOD is divided into two essential components, biological (BSOD) and chemical (CSOD). The former is described by monod kinetics; the latter is accounted for by first-order kinetics. Higashino and Stefan (2005) formulated and solved a numerically unsteady model, which relates SOD to sediment processes and bulk water oxygen by coupling diffusive transport of oxygen in two adjacent layers at the sediment-water interface. In their model, transfer of oxygen to the sediments is represented by diffusion through a boundary layer separating the interface from bulk water, whereas penetration into the sediment layer is accounted for by diffusion with oxygen uptake represented by monod or zero-order kinetics. Using steady-state compartmental models, Di Toro (2001) developed steady-state solutions for methane and nitrogen, and chemical SOD, by solving a coupled system of diffusive-reactive equations expressed in terms of the sediment depth. Di Toro (2001) provides a comprehensive analysis of primarily compartmental dynamic sediment flux models for, among others, nutrients and sulfide in a sediment layer with distinct redox zones. Recently, Hantush (2007) derived unsteady solutions for pore-water nitrogen and methane and their dissolved and gaseous fluxes, and oxygen consumption by oxidation reactions in sediments receiving flux of settling organic matter and interacting with the bulk water through a diffusional boundary layer. These physically based computation algorithms will be included in the future version. 


\section{References}

Baly, E.C.C. 1935. The kinetics of photosynthesis. In Proc. Royal Soc. London Ser. B 117:218-239.

Banks, R.B., and F.F. Herrera. 1977. Effect of wind and rain on surface reaeration. J. Environ Engr. Div. 103(EE3):489-504.

Boudreau, B.P., and B.B. Joergensen. 2001. The benthic boundary layer. London: Oxford University Press.

Carpenter, S.R., N.F. Caraco, D.L. Correll, R.W. Howarth, A.N. Sharpley, and V.H. Smith. 1998. Nonpoint pollution of surface waters with phosphorus and nitrogen. Ecological Applications 8:559-568.

Cerco, C.F., and T. Cole. 1995. User's guide to the CE-QUAL-ICM three-dimensional eutrophication model, Release Version 1.o. Technical Report EL-95-15. Vicksburg, MS: U.S. Army Engineer Waterways Experiment Station.

Chapra, S.C. 1997. Surface water-quality modeling. New York: McGraw-Hill.

Chapra, S.C., and R.P. Canale. 2002. Numerical methods for engineers. New York: McGraw-Hill.

Chapra, S.C., G.J. Pelletier, and H. Tao. 2005. QUAL2K: A modeling framework for simulating river and stream water quality, Version 2.04: Documentation and users manual. Medford, MA: Civil and Environmental Engineering Dept., Tufts University.

Churchill, M.A., H.L. Elmore, and R.A Buckingham. 1962. The prediction of stream reaeration rates. J. Sanit. Engrg. Div. 88(4):1-46.

Cole, T.M., and S.A. Wells. 2003. CE-QUAL-W2: A two-dimensional, laterally averaged, hydrodynamic and water quality model, Version 3.1. Instruction Report EL03-1. Vicksburg, MS: U.S Army Engineering and Research Development Center.

Correll, D.L. 1998. The role of phosphorus in the eutrophication of receiving waters: A review. J. Environ. Qual. 27:261-267.

DiToro, D.M. 2001. Sediment flux modeling. New York: Wiley.

Droop, M.R. 1974. The nutrient status of algal cells in continuous culture. J. Mar. Biol. Assoc. UK 54:825-855.

Fillos, J. and A.H. Molof. 1972. Effect of benthal deposits on oxygen and nutrient economy of flowing waters. J. Water Poll. Contr. Fed. 44(4):644-62.

Hantush, M. 2007. Modeling nitrogen-carbon cycling and oxygen consumption in bottom sediments. Science Direct - Advances in Water Resources Engineering 30(1):10010-1710. 
Higashino, M., and H.G. Stefan. 2005. Oxygen demand by a sediment bed of finite length. J. Environ. Engin. 131(3):350-358.

House, W.A. 2003. Factors influencing the extent and development of the oxic zone in river-bed sediment. Biogeochemistry 63:317-333.

Johnson, B.E. and T.K. Gerald. 2006. Development of a distributed nutrient sub-model (NSM Version 1.o) for watersheds -kinetic process descriptions. ERDC/EL TRo6-12. Vicksburg, MS: U.S. Army Engineer Research and Development Center.

Johnson, B.E., T.K. Gerald, and Z. Zhang. 2007. System-Wide Water Resources Program - nutrient sub-model (SWWRP - NSM) Version 1.1. ERDC/EL TR-07-xx.

Vicksburg, MS: U.S. Army Engineer Research and Development Center.

Melching, C.S. and H.E. Flores. 1999. Reaeration equations from U.S Geological Survey database. J. Environ. Engin. 125(5):407-414.

Meybeck, M. 1982. Carbon, nitrogen, and phosphorus transport by world rivers. American Journal of Science 282: 401-450.

Nakamura, Y., and H.G. Stefan. 1994. Effect of flow velocity on sediment oxygen demand: Theory. J. Environ. Eng. 120(5):996-1016.

O'Connor, D.J., and W.E. Dobbins. 1958. Mechanism of reaeration in natural streams. Trans. ASCE 123:641-684.

Owens, M., R.W. Edwards, and J.W. Gibbs. 1964. Some reaeration studies in streams. Int. J. Air and Water Pollution 8:469-486.

Pinder, G.F. and W.G. Gray. 1977. Finite element simulation in surface and subsurface hydrology. New York: Academic Press.

Smith, E.L. 1936. Photosynthesis in relation to light and carbon dioxide. In Proc. Natl. Acad. Sci. 22:504-511.

Steele, J.H. 1962. Environmental control of photosynthesis in the sea. Limnol. Oceanogr. 7:137-150.

Thackston, E.L. and J.W. Dawson, III. 2001. Recalibration of a reaeration equation. Journal of Environmental Engineering 127(4):317-321.

Walker, R.R. and W.J. Snodgrass. 1985. Modeling sediment oxygen demand in Hamilton Harbor. 56th annual water pollution control federation conference, Atlanta, GA, October 3-7, 1985.

Walsh, J.J., and R.C. Dugdale. 1972. Nutrient submodels and simulation models of phytoplankton production in the sea. In Nutrients in natural waters, ed. H.E. Allen, and J.R. Kramer, 171-191. New York: John Wiley and Sons.

Wang, H.Q., and M. Lacroix. 1997. Optimal weighting in the finite difference solution of the convection-dispersion equation. Science Direct - Journal of Hydrology 200(1-4):10010-1710. 
Wanninkhof, R., I.R. Ledwell, and I. Crusius. 1991. Gas transfer velocities on lakes measured with sulfur hexafluoride. In Symposium Volume of the Second International Conference on Gas Transfer at Water Surfaces, Minneapolis, MN, ed. S.C. Wilhelms and I.S. Gulliver.

Zheng, C., and G.D. Bennett. 1995. Applied contaminant transport modeling: Theory and practice. New York: Van Nostrand Reinhold (now Wiley). 


\section{Appendix A: One-Dimensional Water Quality Transport Equations}

For water quality modeling in streams, the advection-dispersion equation with source/sink terms is one of the governing mass balance equations to be solved numerically. The primary purpose of this appendix is to derive the one-dimensional (1D) governing equations presented in the report.

Any water quality constituent in the stream is transported by the water flow (advection processes) and its concentration is altered by the simultaneous influence of turbulent diffusion processes. The sedimentation of contaminated suspended sediments and the bottom erosion are also important pathways of the "water column-bottom" exchange of constituents. The foundation of the channel water quality transport model is the 1D mass balance equation. The mass balance for each state variable tracks all sources, losses, and internal transformations of water quality constituents in the stream. For each water flow control volume (Figure A1), the geometry is specified by a cell width $B$ length $\Delta x$ and thickness $h$.

1D mass conservation implies that:

$$
\begin{aligned}
\frac{\partial\left(V C_{k}\right)}{\partial t}= & \text { Advection }+ \text { Dispersion }+ \text { Lateral Flow }+ \text { Erosion/Deposition } \\
& + \text { External Sources/Sinks }+ \text { Internal Sources/Sinks (Kinetics) }
\end{aligned}
$$

where:

$C_{k}=$ concentration of constituent $k$ in the channel water [M/L3]

$V=$ volume of the main channel segment [L3]. 


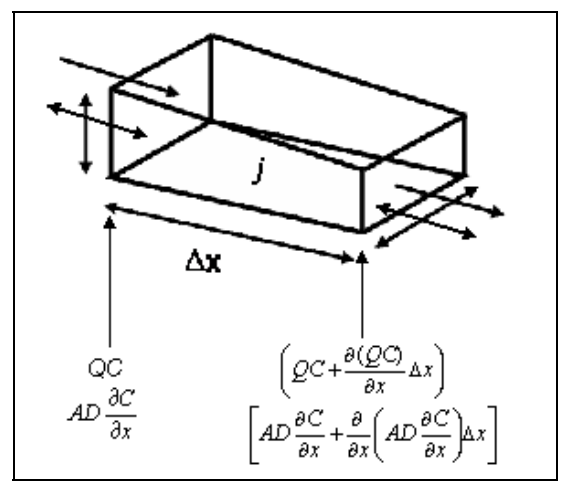

Figure A1. Water quality constituent flux through a 1D control volume

Cross-sectionally averaged variables are often used in channel models. Key processes of Equation A1 that may be part of any water quality transport models are:

- advection-dispersion transport of water flow

- sedimentation and resuspension

- kinetic processes and external sources/sinks

The net mass advected into the control volume and out of the control volume is given by:

$$
\text { Advection }=-\frac{\partial\left(Q C_{k}\right)}{\partial x} \Delta x
$$

where:

$$
\begin{aligned}
Q & =\text { volumetric flow rate }[\mathrm{L} 3 / \mathrm{T}] \\
\Delta x & =\text { lateral distance }[\mathrm{L}] .
\end{aligned}
$$

The net dispersive flux across the control volume is:

$$
\text { Dispersion }=\frac{\partial}{\partial x}\left(A D_{x} \frac{\partial C_{k}}{\partial x}\right) \Delta x
$$

where:

$A=$ channel cross section area of the flow [ $\left[\mathrm{L}^{2}\right]$

$D_{x}=$ dispersion coefficient of constituent $\mathrm{j}$ in the $\mathrm{x}$-direction $\left[\mathrm{L}^{2} / \mathrm{T}\right]$. 
The net mass entering the channel via lateral inflow and leaving through lateral outflow is:

$$
\text { Lateral Flow }=\left(q_{\text {lin }} C_{k l}-q_{\text {lout }} C_{k}\right) \Delta x
$$

where:

$C_{k l}=$ concentration of constituent $k$ in the lateral inflow [M/L3]

$q_{\text {lin }}=$ lateral inflow rate $\left[\mathrm{L}^{2} / \mathrm{T}\right]$

$q_{\text {lout }}=$ lateral outflow rate $\left[\mathrm{L}^{2} / \mathrm{T}\right]$.

The net upward flux of particulate substances near the bed is the difference between erosion and deposition:

$$
\begin{aligned}
\text { Erosion/Deposition } & =\Delta \times B\left(S_{r}-S_{s}\right) \\
& =\Delta \times B\left(\sum_{1}^{N} f_{p n 2} v_{r} C_{k 2}-\sum_{1}^{N} f_{p n} v_{s} C_{k}\right)
\end{aligned}
$$

where:

$$
\begin{aligned}
C_{k 2}= & \text { concentration of constituent } k \text { in the upper layer of the bed } \\
& \text { sediment }\left[\mathrm{M} / \mathrm{L}^{3}\right] \\
S_{r}= & \text { rate per unit bed area at which particulate substance is } \\
& \text { entrained from the bed into the water column }\left[\mathrm{M} / \mathrm{L}^{2} / \mathrm{T}\right] \\
S_{s}= & \text { rate per unit bed area at which particulate substance is } \\
& \text { deposited from the water column onto the sediment bed } \\
& {\left[\mathrm{M} / \mathrm{L}^{2} / \mathrm{T}\right] } \\
B= & \text { width of the channel [L] } \\
v_{r}= & \text { erosion (resuspension) velocity of particulate substances }[\mathrm{L} / \mathrm{T}] \\
v_{s}= & \text { effective settling (deposition) velocity of particulate substances } \\
& {[\mathrm{L} / \mathrm{T}] . }
\end{aligned}
$$

Apart from the transport and sedimentation processes, biochemical transformations significantly affect the concentration distribution of the total substance in the stream. Major transformation processes that should be considered in a stream network system have been specified for each water quality state variable in NSM. Substitution of all terms into Equation $\mathrm{A} 1$ and dividing by $\Delta x$ leads to the following $1 \mathrm{D}$ transport equation for each dissolved state variable: 


$$
\begin{aligned}
\frac{\partial\left(A C_{k}\right)}{\partial t}= & -\frac{\partial\left(Q C_{k}\right)}{\partial x}+\frac{\partial}{\partial x}\left(A D_{x} \frac{\partial C_{k}}{\partial x}\right) \\
& +\left(q_{\text {lin }} C_{k l}-q_{\text {lout }} C_{k}\right)+\sum S_{k, m}+\sum R_{k, m}
\end{aligned}
$$

where:

$$
\begin{aligned}
R_{k, m}= & \text { source/sink term representing internal gains and losses of } \\
& \text { constituent } k \text { due to kinetic reaction } m\left[\mathrm{M} / \mathrm{L}^{2} / \mathrm{T}\right] \\
S_{k, m}= & \text { source/sink term representing external gains and losses of } \\
& \text { constituent } k\left[\mathrm{M} / \mathrm{L}^{2} / \mathrm{T}\right] .
\end{aligned}
$$

If erosion and deposition of suspended sediment occur, the following equation for each particulate state variable is appropriate:

$$
\begin{aligned}
\frac{\partial\left(A C_{k}\right)}{\partial t}= & -\frac{\partial\left(Q C_{k}\right)}{\partial x}+\frac{\partial}{\partial x}\left(A D_{x} \frac{\partial C_{k}}{\partial x}\right)+\left(q_{l i n} C_{k l}-q_{\text {lout }} C_{k}\right) \\
& +B\left(\sum_{1}^{N} f_{p n 2} v_{r} C_{k 2}-\sum_{1}^{N} f_{p n} v_{s} C_{k}\right)+\sum S_{k, m}+\sum R_{k, m}
\end{aligned}
$$

Flow in the channel network is modeled by the 1D Saint-Venant equations. The continuity equation (water balance law) accounts for the volume of water in a reach of open channel including inflow, outflow, and storage within the reach.

The $1 \mathrm{D}$ continuity equation is:

$$
\frac{\partial A}{\partial t}=-\frac{\partial Q}{\partial x}+\left(q_{\text {lin }}-q_{\text {lout }}\right)
$$

Taking into account the continuity equation and Equations A2 and A3:

$$
\begin{aligned}
\frac{\partial C_{k}}{\partial t}= & -\frac{Q}{A} \frac{\partial C_{k}}{\partial x}+\frac{1}{A} \frac{\partial}{\partial x}\left(A D_{x} \frac{\partial C_{k}}{\partial x}\right) \\
& +\frac{q_{\text {lin }}}{A}\left(C_{k l}-C_{k}\right)+\sum S_{k, m}+\sum R_{k, m}
\end{aligned}
$$




$$
\begin{aligned}
\frac{\partial C_{k}}{\partial t}= & -\frac{Q}{A} \frac{\partial C_{k}}{\partial x}+\frac{1}{A} \frac{\partial}{\partial x}\left(A D_{x} \frac{\partial C_{k}}{\partial x}\right)+\frac{q_{l i n}}{A}\left(C_{k l}-C_{k}\right) \\
& +\frac{1}{h}\left(\sum_{1}^{N} f_{p n 2} v_{r} C_{k 2}-\sum_{1}^{N} f_{p n} v_{s} C_{k}\right)+\sum S_{k, m}+\sum R_{k, m}
\end{aligned}
$$

The general mass balance equation for $1 \mathrm{D}$ transport considering advection-dispersion with source/sink terms is rewritten as:

$$
\frac{\partial C}{\partial t}=-\frac{Q}{A} \frac{\partial C}{\partial x}+\frac{1}{A} \frac{\partial}{\partial x}\left(A D_{x} \frac{\partial C}{\partial x}\right)+\sum S_{k}+\sum R_{k}
$$

where:

$\sum S_{k}$ and $\sum R_{k}$ denote total external and internal (kinetic) source/sink terms, respectively.

In order to provide a complete description of the dominant pools and fluxes in the water column, NSM takes into account water quality transport processes in the bed sediment (Figure A2). The mass balance approach is greatly simplified as the processes of advection, dispersion, and lateral inflow do not affect the bed sediment layer. For each upper layer of bed sediment, water quality dynamics in the upper active layer of bed sediments for each dissolved state variable and each particulate state variable can be described as:

$$
\begin{gathered}
\frac{\partial\left(V_{2} C_{k 2}\right)}{\partial t}=\sum S_{k 2, m}+\sum R_{k 2, m} \\
\frac{\partial\left(V_{2} C_{k 2}\right)}{\partial t}= \\
=\Delta x B\left(-\sum_{1}^{N} f_{p n 2} v_{r} C_{k 2}+\sum_{1}^{N} f_{p n} v_{s} C_{k}\right) \\
+\sum S_{k 2, m}+\sum R_{k 2, m}
\end{gathered}
$$

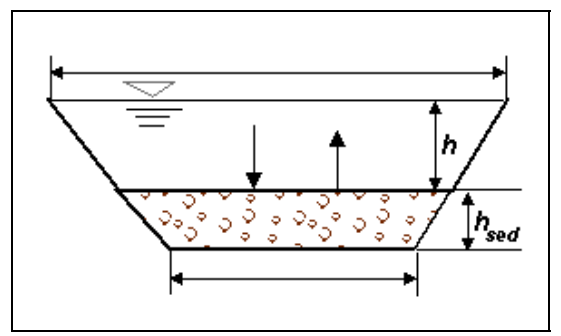

Figure A2. Schematic representation of benthic sediment 


\section{Appendix B: One-Dimensional Finite Difference Equations and Numerical Solutions}

The transport equations described in Appendix A must be solved simultaneously for all phases of the constituent. It is not possible to solve the coupled equations analytically for a general case. Therefore numerical techniques must be used. This appendix is devoted to the formulation of finite difference (FD) equations and numerical solutions. The FD equations are formulated from the original partial differential equations (PDEs).

\section{Finite difference approximation equations}

The general mass balance equation of $1 \mathrm{D}$ transport considering advectiondispersion with source/sink terms for a dissolved or suspended substance represented by the concentration $C$ is:

$$
\frac{\partial C}{\partial t}=-u_{x} \frac{\partial C}{\partial x}+\frac{1}{A} \frac{\partial}{\partial x}\left(A D_{x} \frac{\partial C}{\partial x}\right)+\sum S_{k}+\sum R_{k}
$$

where:

$$
\begin{aligned}
C & =\text { concentration (dissolved or particulate phase) }[\mathrm{M} / \mathrm{L} 3] \\
u_{x} & =\text { depth averaged } \mathrm{x} \text {-direction (longitudinal) velocity }[\mathrm{L} / \mathrm{T}] \\
\sum S_{k} \text { and } \sum R_{k} & =\text { external and internal source/sink terms, respectively. }
\end{aligned}
$$

A common method of solving PDEs is to approximate the spatial derivatives $(\partial / \partial x$ and $\partial / \partial y)$ using finite difference methods (FDMs). The FDM can be used to solve these equations numerically in a relatively simple, convenient, and economical manner. To implement an FD scheme, the channel reach is first spatially discretized into a computational domain composed of a number of non-overlapping control volumes within which mass is conserved. Figure B1 depicts a discretized stream network system. 


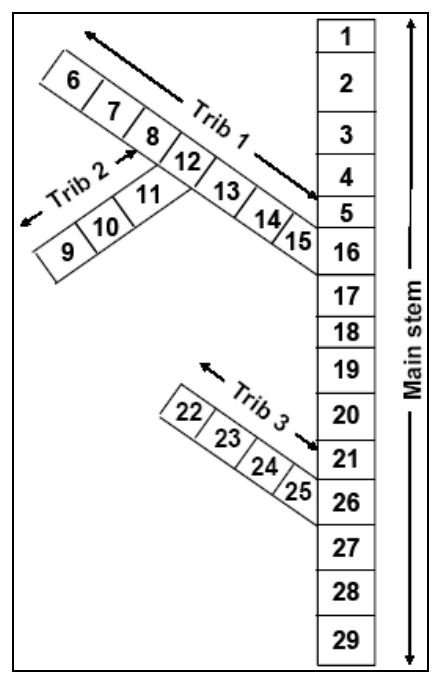

Figure B1. Conceptual stream network system

Referring to Figure B2, the first derivatives representing the advection and dispersion terms of Equation B1 for cell ( $j$ ) can be approximated as follows:

$$
\begin{aligned}
\text { Advection } & =\left(-u_{x} \frac{\partial C}{\partial x}\right)_{j}=-u_{x j} \frac{C_{j+1 / 2}-C_{j-1 / 2}}{\Delta x_{j}} \\
\text { Dispersion } & =\left[\frac{1}{A} \frac{\partial}{\partial x}\left(A D_{x} \frac{\partial C}{\partial x}\right)\right]_{j} \\
& =\frac{1}{A_{j}} \frac{\left(A D_{x} \frac{\partial C}{\partial x}\right)_{j+1 / 2}-\left(A D_{x} \frac{\partial C}{\partial x}\right)_{j-1 / 2}}{\Delta x_{j}}
\end{aligned}
$$

In order to outline the derivation of the FDM, one must start with the1D advection-dispersion equation.

The FD equation for 1D transport considering advection-dispersion without the source/sink term can be written as:

$$
\begin{aligned}
\frac{C_{j}^{n+1}-C_{j}^{n}}{\partial t}= & -u_{x j}^{*} \frac{C_{j+1 / 2}^{*}-C_{j-1 / 2}^{*}}{\Delta x_{j}} \\
& +\frac{1}{A_{j}^{*}} \frac{\left(A D_{x} \frac{\partial C}{\partial x}\right)_{j+1 / 2}^{*}-\left(A D_{x} \frac{\partial C}{\partial x}\right)_{j-1 / 2}^{*}}{\Delta x_{j}}
\end{aligned}
$$


where:

$$
\begin{aligned}
j= & \text { current location } \\
j-1 \text { and } j+1= & \text { positions removed and increased a value } x \text { from the } \\
& \text { current location in the solution scheme, respectively } \\
j-1 / 2 \text { and } j+1 / 2= & \text { left and right interfaces of cell }(\mathrm{j}), \text { respectively } \\
* & =\text { appropriate time level, which will be determined later. }
\end{aligned}
$$

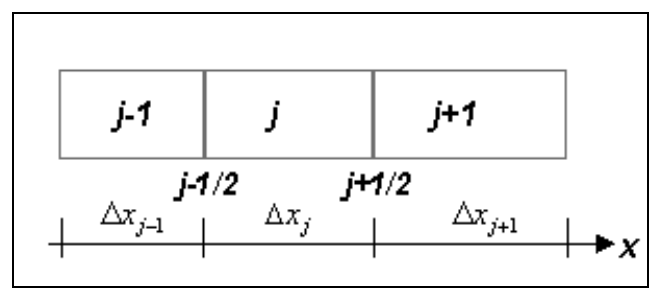

Figure B2. 1D FD computational mesh

Equation $\mathrm{B} 4$ is the standard form of the FD approximation. The interface concentration values depend upon the appropriate interpolation procedure for the FD scheme. How the interface concentration is determined is what distinguishes one solution technique from another. In the standard finite-difference method, the interface concentration is evaluated using either the upstream or the central-in-space weighting scheme. For the upstream weighting scheme, the interface concentration between two neighboring nodes is set equal to the concentration at the upstream node along the same direction:

$$
C_{j-1 / 2}=\left\{\begin{array}{l}
C_{j-1}, \quad \text { if } u_{x j-1 / 2}>0 \\
C_{j}, \quad \text { if } u_{x j-1 / 2}<0
\end{array}\right.
$$

Most FDMs for calculating the advection term are plagued by problems of numerical oscillations and/or artificial or numerical dispersion. The upstream weighting scheme results in oscillation-free solutions. However, the solution of the advection term is only accurate to the first order, which can lead to significant numerical dispersion, since the truncation error resulting from the advection solution is of the same order and could overwhelm the second-derivative physical dispersion term (Zheng and Bennett 1995).

For the central-in-space weighting scheme, the interface concentration is set equal to the weighted average of the concentrations on the two sides of the interface: 


$$
\begin{gathered}
C_{j-1 / 2}=\frac{\Delta x_{j}}{\Delta x_{j-1}+\Delta x_{j}} C_{j-1}+\frac{\Delta x_{j-1}}{\Delta x_{j-1}+\Delta x_{j}} C_{j}=\left(1-\alpha_{x j-1 / 2}\right) C_{j-1}+\alpha_{x j-1 / 2} C_{j}(\mathrm{~B} 6) \\
C_{j+1 / 2}=\frac{\Delta x_{j+1}}{\Delta x_{j}+\Delta x_{j+1}} C_{j}+\frac{\Delta x_{j}}{\Delta x_{j}+\Delta x_{j+1}} C_{j+1}=\left(1-\alpha_{x j+1 / 2}\right) C_{j}+\alpha_{x j+1 / 2} C_{j+1}(\mathrm{~B} 7) \\
\left(\frac{\partial C}{\partial x}\right)_{j-1 / 2}=\frac{C_{j}-C_{j-1}}{0.5\left(\Delta x_{j-1}+\Delta x_{j}\right)} \\
\left(\frac{\partial C}{\partial x}\right)_{j+1 / 2}=\frac{C_{j+1}-C_{j}}{0.5\left(\Delta x_{j}+\Delta x_{j+1}\right)}
\end{gathered}
$$

where:

$$
\begin{aligned}
& \alpha_{x j+1 / 2}=\frac{\Delta x_{j}}{\Delta x_{j}+\Delta x_{j+1}} \\
& \alpha_{x j-1 / 2}=\frac{\Delta x_{j-1}}{\Delta x_{j-1}+\Delta x_{j}}
\end{aligned}
$$

Substitution of all terms into Equations B2 and B3 leads to the following equations:

\section{Advection}

$$
\begin{aligned}
& =-\frac{1}{\Delta x_{j}} u_{x j}\left(\frac{\Delta x_{j+1}}{\Delta x_{j}+\Delta x_{j+1}} C_{i}+\frac{\Delta x_{j}}{\Delta x_{j}+\Delta x_{j+1}} C_{j+1}-\frac{\Delta x_{j}}{\Delta x_{j-1}+\Delta x_{j}} C_{j-1}-\frac{\Delta x_{j-1}}{\Delta x_{j-1}+\Delta x_{j}} C_{j}\right) \\
& =-\frac{1}{\Delta x_{j}} u_{x j}\left(\left(1-\alpha_{x j+1 / 2}\right) C_{j}+\alpha_{x j+1 / 2} C_{j+1}-\left(1-\alpha_{x j-1 / 2}\right) C_{j-1}-\alpha_{x j-1 / 2} C_{j}\right)
\end{aligned}
$$

Dispersion $=\frac{1}{\Delta x_{j}} \frac{1}{A_{j}}\left(\left(A D_{x}\right)_{j+1 / 2} \frac{C_{j+1}-C_{j}}{0.5\left(\Delta x_{j+1}+\Delta x_{j}\right)}-\left(A D_{x}\right)_{j-1 / 2} \frac{C_{j}-C_{j-1}}{0.5\left(\Delta x_{j-1}+\Delta x_{j}\right)}\right)$ 


\section{Time weighting and central-in-space weighting scheme}

Substituting the FD approximations into the PDEs yields a set of algebraic equations. Depending upon the manner in which the FDs are computed, the algebraic equations may be solved with either an explicit or an implicit scheme. With an explicit scheme, the unknown values are found recursively. The results of one computation are necessary for the next. With an implicit scheme, all the unknown values for a given time are found simultaneously. There are limitations for the explicit method based on the stability criterion associated with them, so the size of time steps cannot exceed a certain value. Due to these limitations, the explicit scheme is not commonly used in constituent transport. As a result, one would naturally consider their implicit formulations as an alternative to avoid unstable solutions. The implicit space-centered finite difference scheme is second-order accurate in both space and time with a small truncation error. With the central-in-space weighting scheme the solution of the advection term is accurate to the second order and as a result it does not lead to any numerical dispersion since the solution of the dispersion term is also accurate to the second order. However if the transport problem is advection-dominated, the central-in-space weighting scheme can lead to excessive artificial oscillation, which is typical of higher-order truncation errors. Pinder and Gray (1977) noted that numerical solutions of the advection-dispersion equation are characterized by two principal phenomena: numerical dispersion and oscillation (over- or undershoot) with these phenomena being closely related. When a numerical scheme is developed to minimize the numerical dispersion, oscillation is encountered but when the oscillation is controlled, it is generally at the expense of increased numerical dispersion. Numerical dispersion and artificial oscillation limit the reliability of numerical solutions of the advection-dispersion equation when FDMs are used (Wang and Lacroix 1997). Because of the dual problems of numerical dispersion and artificial oscillation, the standard FDMs are suitable only for solving transport models not dominated by advection (i.e., when either the physical dispersivity is large or the grid spacing is made sufficiently fine).

Applying time weighting and a central-in-space weighting scheme, the spatial derivatives are made at both the present and the future time step. These FD approximations are then averaged to obtain a spatial approximation that corresponds to the midpoint of the time step. Equation B4 at any finite difference cell ( $j$ ) can be expressed as follows: 


$$
\begin{aligned}
\frac{C_{j}^{n+1}-C_{j}^{n}}{\Delta t}= & -\omega u_{j+1 / 2}^{n+1} \frac{C_{j+1 / 2}^{n+1}-C_{j-1 / 2}^{n}}{\Delta x_{j}}-(1-\omega) u_{x j}^{n} \frac{C_{j+1 / 2}^{n+1}-C_{j-1 / 2}^{n}}{\Delta x_{j}} \\
& +\omega \frac{1}{A_{j}^{n+1}} \frac{\left(A D_{x} \frac{\alpha c}{\alpha x}\right)_{j+1 / 2}^{n+1}-\left(A D_{x} \frac{\alpha c}{\alpha x}\right)_{j-1 / 2}^{n+1}}{\Delta x_{j}} \\
& +(1-\omega) \frac{1}{A_{j}^{n}} \frac{\left(A D_{x} \frac{\alpha c}{\alpha x}\right)_{j+1 / 2}^{n}-\left(A D_{x} \frac{\alpha c}{\alpha x}\right)_{j-1 / 2}^{n}}{\Delta x_{j}}
\end{aligned}
$$

where:

$$
\begin{aligned}
& \omega=\text { time weighting coefficient for semi-implicit schemes } \\
& \quad(0 \leq \omega \leq 1) .
\end{aligned}
$$

When $\omega=O$ the solution scheme is explicit and when $\omega=1$ the scheme is implicit. If $=0.5$, Equation B14 becomes the well-known CrankNicolson (C-N) FD scheme approximation.

Substitution of all interface terms into Equation B14 leads to the following equation:

$$
\begin{aligned}
\frac{C_{j}^{n+1}-C_{j}^{n}}{\Delta t}= & -\omega \frac{1}{\Delta x_{j}} u_{x j}^{n+1}\left(\begin{array}{l}
\left(1-\alpha_{x j+1 / 2}\right) C_{j}^{n+1}+\alpha_{x j+1 / 2} C_{j+1}^{n+1} \\
-\left(1-\alpha_{x j-1 / 2}\right) C_{j-1}^{n+1}-\alpha_{x j-1 / 2} C_{j}^{n+1}
\end{array}\right) \\
& -(1-\omega) \frac{1}{\Delta x_{j}} u_{x j}^{n}\left(\begin{array}{l}
\left(1-\alpha_{x j+1 / 2}\right) C_{j}^{n}+\alpha_{x j+1 / 2} C_{j+1}^{n} \\
-\left(1-\alpha_{x j-1 / 2}\right) C_{j-1}^{n}-\alpha_{x j-1 / 2} C_{j}^{n}
\end{array}\right) \\
& +\omega \frac{1}{\Delta x_{j}} \frac{1}{A_{j}^{n+1}}\left(\begin{array}{l}
\left(A D_{x}\right)_{j+1 / 2}^{n+1} \frac{C_{j+1}^{n+1}-C_{j}^{n+1}}{0.5\left(\Delta x_{j}+\Delta x_{j+1}\right)} \\
\left.-\left(A D_{x}\right)_{j-1 / 2}^{n+1} \frac{C_{j}^{n+1}-C_{j-1}^{n+1}}{0.5\left(\Delta x_{j-1}+\Delta x_{j}\right)}\right) \\
\end{array}\right. \\
& +(1-\omega) \frac{1}{\Delta x_{j}} \frac{1}{A_{j}^{n}}\left(\begin{array}{l}
\left(A D_{x}\right)_{j+1 / 2}^{n+1} \frac{C_{j+1}^{n}-C_{j}^{n}}{0.5\left(\Delta x_{j}+\Delta x_{j+1}\right)} \\
\left.-\left(A D_{x}\right)_{j-1 / 2}^{n+1} \frac{C_{j}^{n}-C_{j-1}^{n}}{0.5\left(\Delta x_{j-1}+\Delta x_{j}\right)}\right)
\end{array}\right.
\end{aligned}
$$

This, in turn, may be simplified by collecting terms: 


$$
E_{j} C_{j-1}^{n+1}+F_{j} C_{j}^{n+1}+G_{j} C_{j+1}^{n+1}=S S_{j}
$$

where:

$E, F$, and $G$ are matrix coefficients and $S S$ is a forcing function.

For the interior segments of the channel (from $j=2$ to $j=m-1$ ) the matrix coefficients $(E, F, G)$ and the forcing function $(S S)$ are computed as follows:

$$
\begin{gathered}
E_{j}=-\omega \frac{1}{\Delta x_{j}}\left(u_{x j}^{n+1}\left(1-\alpha_{x j-1 / 2}\right)+\frac{1}{A_{j}^{n+1}} \frac{\left(A D_{x}\right)_{j-1 / 2}^{n+1}}{0.5\left(\Delta x_{j-1}+\Delta x_{j}\right)}\right) \\
\left.F_{j=} \frac{1}{\Delta t}+\omega \frac{1}{\Delta x_{j}} \int_{x j}^{u_{x j}^{n+1}\left[\left(1-\alpha_{x j+1 / 2}\right)-\alpha_{x j-1 / 2}\right]}+\frac{1}{0.5 A_{j}^{n+1}}\left(\frac{\left(A D_{x}\right)_{j+1 / 2}^{n+1}}{\Delta x_{j}+\Delta x_{j+1}}+\frac{\left(A D_{x}\right)_{j-1 / 2}^{n+1}}{\Delta x_{j-1}+\Delta x_{j}}\right)\right] \\
S S_{j}=\frac{C_{j}^{n}}{\Delta t}+(1-\omega) \frac{1}{\Delta x_{j}} u_{x j}^{n}\left[\left(1-\alpha_{x j-1 / 2}\right) C_{j-1}^{n}-\left(\left(1-\alpha_{x j+1 / 2}\right)-\alpha_{x j-1 / 2}\right) C_{j}^{n}-\alpha_{x j+1 / 2} C_{j+1}^{n}\right] \\
+(1-\omega) \frac{1}{0.5 \Delta x_{j} A_{j}^{n}}\left[\frac{\left(A D_{x}\right)_{j-1 / 2}^{n}}{\Delta x_{j-1}+\Delta x_{j}} C_{j-1}^{n}-\left(\frac{\left(A D_{x}\right)_{j-1 / 2}^{n}}{\Delta x_{j-1}+\Delta x_{j}}+\frac{\left(A D_{x}\right)_{j+1 / 2}^{n}}{\Delta x_{j}+\Delta x_{j+1}}\right) C_{j}^{n}+\frac{\left.\left(A D_{x}\right)_{j+1 / 2}^{n}\right)_{j+1 / 2}^{n+1}}{\Delta x_{j}+\Delta x_{j+1}} C_{j+1}^{n}\right]
\end{gathered}
$$

The application of the time weighting and central-in-space weighting finite difference schemes for all inner cells, within the watershed, results in a set of tridiagonal linear equations. These equations must be solved simultaneously to obtain the concentration $C_{j}^{n+1}$.

A set of tridiagonal equations representing $M$ cells system is shown below: 


$$
\left[\begin{array}{ccccccc}
F_{1} & G_{1} & & & & & \\
E_{2} & F_{2} & G_{2} & & & & \\
& E_{3} & F_{3} & G_{3} & & & \\
& & \cdot & \cdot & \cdot & & \\
& & & \cdot & \cdot & \cdot & \\
& & & & E_{m-1} & F_{m-1} & G_{m-1} \\
& & & & & E_{m} & F_{m}
\end{array}\right]\left[\begin{array}{c}
C_{1}^{n+1} \\
C_{2}^{n+1} \\
C_{3}^{n+1} \\
\cdot \\
\cdot \\
C_{m-1}^{n+1} \\
C_{m}^{n+1}
\end{array}\right]=\left[\begin{array}{c}
S S_{1} \\
S S_{2} \\
S S_{3} \\
\cdot \\
\cdot \\
S S_{m-1} \\
S S_{m}
\end{array}\right]
$$

The source/sink terms must be specified for each water quality component in order to solve transport Equation B1.

\section{Boundary conditions}

Boundary conditions must be defined at upstream and downstream boundary cells. Through these cells, material is exchanged with the environment outside the channel reach. An upstream boundary condition is shown in Figure B3, where the interfacial concentration at the upstream boundary is set to a user-defined concentration $C_{u s}$.

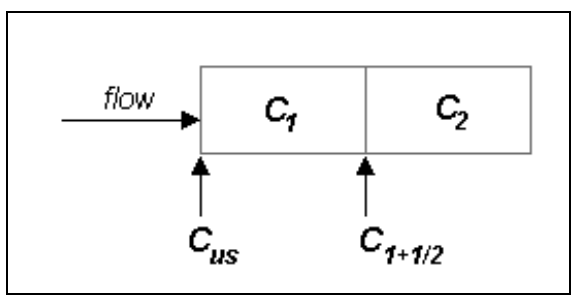

Figure B3. Upstream boundary condition

For the first segment of the channel $(j=1)$, the matrix coefficients $(E, F, G)$ and the forcing function $(S S)$ are computed as follows:

$$
\begin{gathered}
F_{1}=\frac{1}{\Delta t}+\omega \frac{1}{\Delta x_{1}}\left[u_{x 1}^{n+1} \frac{\Delta x_{2}}{\Delta x_{1}+\Delta x_{2}}+\frac{1}{0.5 A_{1}^{n+1}}\left(\frac{\left(A D_{x}\right)_{1+1 / 2}^{n+1}}{\Delta x_{1}+\Delta x_{2}}+\frac{\left(A D_{x}\right)_{u s}^{n+1}}{\Delta x_{1}}\right)\right] \\
G_{1}=\omega \frac{1}{\Delta x_{1}}\left(u_{x 1}^{n+1} \frac{\Delta x_{1}}{\Delta x_{1}+\Delta x_{2}}-\frac{1}{0.5 A_{1}^{n+1}} \frac{\left(A D_{x}\right)_{1+1 / 2}^{n+1}}{\Delta x_{1}+\Delta x_{2}}\right)
\end{gathered}
$$




$$
\begin{aligned}
S S_{1}= & \frac{C_{1}^{n}}{\Delta t}-(1-\omega) \frac{1}{\Delta x_{1}} u_{x 1}^{n}\left(\frac{\Delta x_{2}}{\Delta x_{1}+\Delta x_{2}} C_{1}^{n}+\frac{\Delta x_{1}}{\Delta x_{1}+\Delta x_{2}} C_{2}^{n}\right) \\
& +(1-\omega) \frac{1}{\Delta x_{1}} u_{x 1}^{n} C_{u s}^{n}+\omega \frac{1}{\Delta x_{1}} u_{x 1}^{n+1} C_{u s}^{n+1} \\
& +(1-\omega) \frac{1}{0.5 \Delta x_{1} A_{1}^{n}}\left[-\left(\frac{\left(A D_{x}\right)_{u s}^{n}}{\Delta x_{1}}+\frac{\left(A D_{x}\right)_{1+1 / 2}^{n}}{\Delta x_{1}+\Delta x_{2}}\right) C_{1}^{n}+\frac{\left(A D_{x}\right)_{1+1 / 2}^{n}}{\Delta x_{1}+\Delta x_{2}} C_{2}^{n}\right] \\
& +(1-\omega) \frac{1}{0.5 \Delta x_{1}^{2}} \frac{\left(A D_{x}\right)_{u s}^{n}}{A_{1}^{n}} C_{u s}^{n}+\omega \frac{1}{0.5 \Delta x_{1}^{2}} \frac{\left(A D_{x}\right)_{u s}^{n+1}}{A_{1}^{n+1}} C_{u s}^{n+1}
\end{aligned}
$$

A downstream boundary condition is shown in Figure B4 where the dispersive flux at the downstream boundary is set to a user-defined flux, Flux ds.

$$
\left(D_{x} \frac{\partial C}{\partial x}\right)_{m+1 / 2}=F l u x_{d s}
$$

In many applications the flux represented by the downstream boundary condition is set to zero. Using the definition of the interfacial first derivative given by Equation B13 and assuming $\Delta x_{m+1}=\Delta x_{m}$, the concentration in the cell adjoining the boundary $C_{m+1}$ is computed as:

$$
C_{m+1}=C_{m}+\frac{\Delta x_{m} \text { Flux }_{d s}}{D_{x m+1 / 2}}
$$

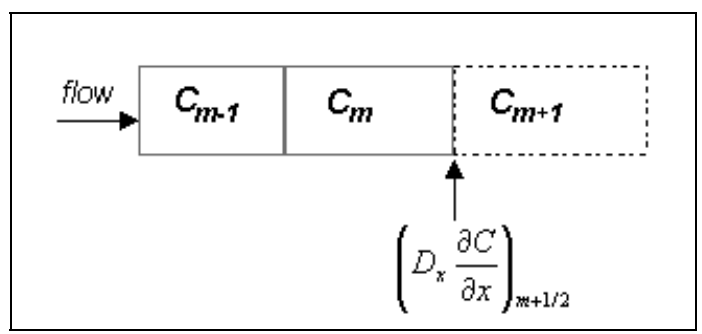

Figure B4. Downstream boundary condition

For the last segment of the channel $(j=m)$ the matrix coefficients $(E, F, G)$ and the forcing function $(S S)$ are computed as follows: 


$$
\begin{aligned}
E_{m} & =-\omega \frac{1}{\Delta x_{m}}\left(u_{x m}^{n+1} \frac{\Delta x_{m}}{\Delta x_{m-1}+\Delta x_{m}}+\frac{1}{0.5 A_{m}^{n+1}} \frac{\left(A D_{x}\right)_{m-1 / 2}^{n+1}}{\left(\Delta x_{m-1}+\Delta x_{m}\right)}\right) \\
F_{m}= & \frac{1}{\Delta t}+\omega \frac{1}{\Delta x_{m}}\left[u_{x m}^{n+1}\left(1-\frac{\Delta x_{m-1}}{\Delta x_{m-1}+\Delta x_{m}}\right)+\frac{1}{0.5 A_{m}^{n+1}} \frac{\left(A D_{x}\right)_{m-1 / 2}^{n+1}}{\Delta x_{m-1}+\Delta x_{m}}\right] \\
S S_{m}= & \frac{C_{m}^{n}}{\Delta t}+(1-\omega) u_{x m}^{n}\left[\frac{1}{\Delta x_{m-1}+\Delta x_{m}} C_{m-1}^{n}-\frac{1}{\Delta x_{m-1}+\Delta x_{m}} C_{m}^{n}\right] \\
& -(1-\omega) \frac{u_{x m}^{n}}{2 D_{x m+1 / 2}^{n}} F l u x_{d s}-\omega \frac{u_{x m}^{n+1}}{2 D_{x m+1 / 2}^{n+1}} F l u x_{d s} \\
& +(1-\omega) \frac{1}{0.5 \Delta x_{m} A_{m}^{n}}\left[\frac{\left(A D_{x}\right)_{m-1 / 2}^{n}}{\Delta x_{m-1}+\Delta x_{m}} C_{m-1}^{n}-\frac{\left(A D_{x}\right)_{m-1 / 2}^{n}}{\Delta x_{m-1}+\Delta x_{m}} C_{m}^{n}\right] \\
& +(1-\omega) \frac{1}{\Delta x_{m}} \frac{A_{m+1 / 2}^{n}}{A_{m}^{n}} F l u x_{d s}+\omega \frac{1}{\Delta x_{m}} \frac{A_{m+1 / 2}^{n+1}}{A_{m}^{n+1}} F l u x_{d s}
\end{aligned}
$$

Solution of Equation B16 requires that the flow area and the crosssectional average velocities for each node be obtained first from the solution of the flow equations. If the flow model itself does not provide flow velocities directly, they must be derived by dividing the flow rates $Q_{j}$ by the flow areas $A_{i}$ for each node, e.g., $u_{x j}=Q_{j} / A_{j}$. The procedure applied at each time step is to first solve the flow equations and then, given the flow areas and velocities, solve the advection-dispersion transport equation to obtain concentrations.

\section{Thomas algorithm}

Tridiagonal coefficient matrix Equation B16, subject to appropriate initial and boundary conditions, can be solved using an efficient formulation of the Thomas algorithm (Chapra and Canale 2002). The Thomas algorithm is a very efficient way of solving tridiagonal linear systems and is therefore the solver of choice for most $1 \mathrm{D}$ models. It is also useful for $2 \mathrm{D}$ models that have been discretized by a finite difference scheme leading to a tridiagonal linear system. The matrix itself is not stored; only three vectors $(E, F, G)$ are stored. These hold the values on the matrix diagonals. 
For a tridiagonal matrix equation: $[A]\{x\}=\{b\}$, the Thomas algorithm computational procedure consists of three steps:

1. Decomposing $[A]$ into a product of lower-diagonal $[L]$ and upperdiagonal $[U]$ matrices: $[L][U]=[A]$.

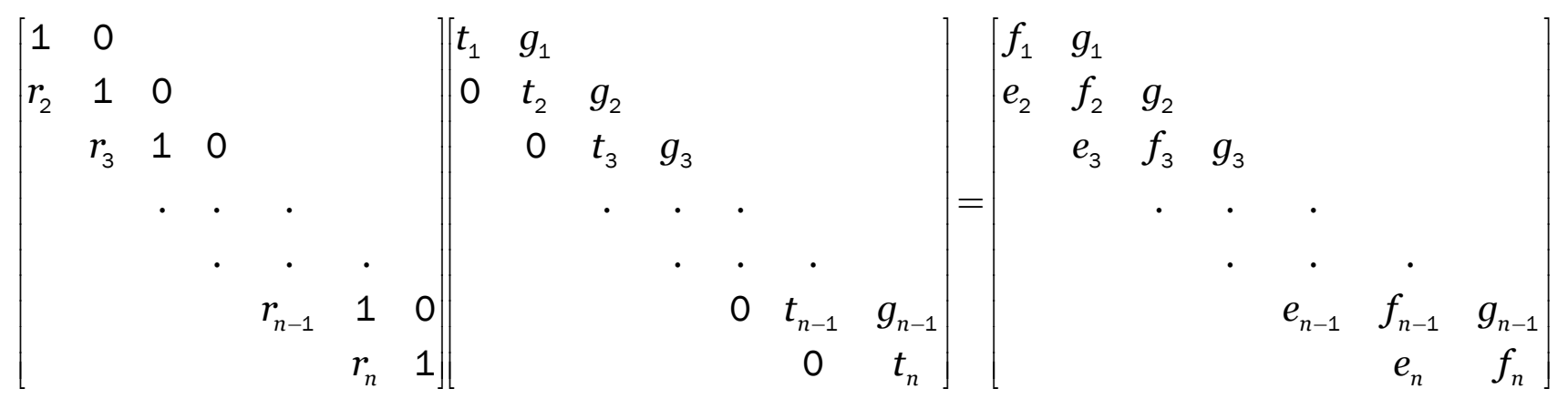

By considering the multiplication of $[L]$ and $[U]$ :

$$
\begin{gathered}
r_{i}=e_{i} / t_{i-1} \\
t_{i}=f_{i}-r_{i} g_{i-1}
\end{gathered}
$$

Thus the values of $r$ and $t$ may be computed in the order $1,2, \ldots, n$.

2. Forward substitution is through an intermediate vector $\{d\}:[L]\{d\}=\{b\}$; thus $\{d\}=[L]^{-1}\{b\}$ :

$$
\left[\begin{array}{ccccccc}
1 & 0 & & & & & \\
r_{2} & 1 & 0 & & & & \\
& r_{3} & 1 & 0 & & & \\
& & \cdot & \cdot & \cdot & & \\
& & & \cdot & \cdot & \cdot & \\
& & & & r_{n-1} & 1 & 0 \\
& & & & & r_{n} & 1
\end{array}\right]\left[\begin{array}{c}
d_{1} \\
d_{2} \\
d_{3} \\
\cdot \\
\cdot \\
d_{n-1} \\
d_{n}
\end{array}\right]=\left[\begin{array}{c}
b_{1} \\
b_{2} \\
b_{3} \\
\cdot \\
\cdot \\
b_{n-1} \\
b_{n}
\end{array}\right]
$$

Inspecting the multiplication allows inversion of $[L]$ :

$$
d_{1}=b_{1}
$$




$$
d_{i}=b_{i}-r_{i} d_{i-1}
$$

Thus values of $\{d\}$ may be computed in the order $1,2, \ldots, n$.

3. Backward substitution to give the final solution: $[U]\{x\}=\{d\}$ thus $\{x\}=[U]^{-1}\{d\}$ :

$$
\left[\begin{array}{ccccccc}
t_{1} & g_{1} & & & & & \\
0 & t_{2} & g_{2} & & & & \\
& 0 & t_{3} & g_{3} & & & \\
& & \cdot & \cdot & \cdot & & \\
& & & \cdot & \cdot & \cdot & \\
& & & & 0 & t_{n-1} & g_{n} \\
& & & & & 0 & t_{n}
\end{array}\right]\left[\begin{array}{c}
x_{1} \\
x_{2} \\
x_{3} \\
\cdot \\
\cdot \\
x_{n-1} \\
x_{n}
\end{array}\right]=\left[\begin{array}{c}
d_{1} \\
d_{2} \\
d_{3} \\
\cdot \\
\cdot \\
d_{n-1} \\
d_{n}
\end{array}\right]
$$

Again, inspecting the multiplication gives the effective inverse of $[U]$

$$
\begin{gathered}
x_{n}=d_{n} / t_{n} \\
x_{i}=\left(d_{i}-g_{i} x_{j+1}\right) / t_{i}
\end{gathered}
$$

Thus values of $\{x\}$ may be computed in the order $n, n-1, \ldots, 1$.

\section{Numerical implementation}

Many numerical approaches could be implemented to solve the coupled FD equations. All sources/sinks for water quality modeling are separated into two groups: internal and external terms. The division of terms allows kinetic sources/sinks to be updated at different frequencies than external sources/sinks - consistent with the coarser time scales associated with biological and chemical processes as opposed to hydrologic transport. This separation also allows computation times to be reduced. The source/sink term represents a mass rate of change $[\mathrm{M} / \mathrm{T}]$ of a water quality constituent. By separating the kinetic components (NSM) and transport components (HEC-RAS, ADH, GSSHA), the complete water quality mass balance transport equations are solved through a step-by-step procedure: 
1. Evaluate internal sources/sinks due to biochemical transformations and water-sediment fluxes $\left(\sum R_{i}\right)$ by an explicit method. That is, all internal source/sink parameters in the FD equation are evaluated at time $t(n)$.

2. Combine the effects of internal sources/sinks $\left(\sum R_{i}\right)$ and external loading $\left(\sum S_{i}\right.$ ). This step completes computation of all sources/sinks that are contained in the array $S S_{i}$ in the FD equation.

3. Solve the FD equation and compute concentration at time $t+t(n+1)$ using various numerical schemes. This step combines the effect of the two main transport mechanisms (advection and dispersion) with biochemical transformation reaction. 


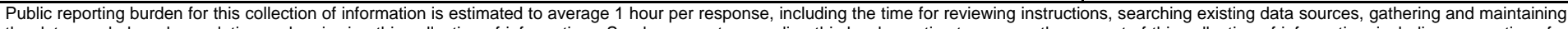

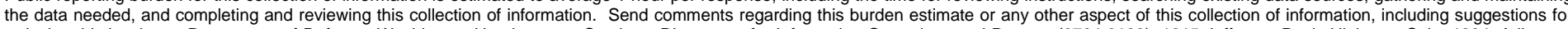

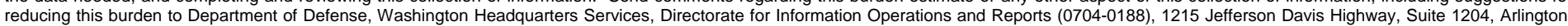

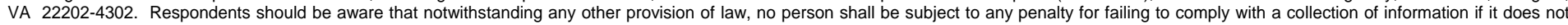
display a currently valid OMB control number. PLEASE DO NOT RETURN YOUR FORM TO THE ABOVE ADDRESS.
1. REPORT DATE (DD-MM-YYYY)
2. REPORT TYPE
3. DATES COVERED (From - To)

June 2009

Final repot

\section{TITLE AND SUBTITLE}

Development of a River and Stream Water Quality Module

5a. CONTRACT NUMBER

5b. GRANT NUMBER

5c. PROGRAM ELEMENT NUMBER

\section{AUTHOR(S)}

Billy E. Johnson and Zhonglong Zhang

5d. PROJECT NUMBER

5e. TASK NUMBER

5f. WORK UNIT NUMBER

\section{PERFORMING ORGANIZATION NAME(S) AND ADDRESS(ES)}

8. PERFORMING ORGANIZATION REPORT NUMBER

U.S. Army Engineer Research and Development Center 3909 Halls Ferry Road

ERDC/EL TR-09-4

Vicksburg, MS 39180-6199

9. SPONSORING I MONITORING AGENCY NAME(S) AND ADDRESS(ES)

10. SPONSOR/MONITOR'S ACRONYM(S)

U.S. Army Corps of Engineers

Washington, DC 20314-1000

11. SPONSOR/MONITOR'S REPORT NUMBER(S)

\section{DISTRIBUTION / AVAILABILITY STATEMENT}

Approved for public release; distribution is unlimited.

\section{SUPPLEMENTARY NOTES}

\section{ABSTRACT}

This report describes the in-stream water quality module within the Nutrient Sub-Model (NSM), Version 1.2. The in-stream water quality module includes the major processes for nitrogen, phosphorus, carbon, and oxygen cycling in a stream. Kinetic process equations are presented for each state variable for water quality modeling in streams. These equations were taken largely from models such as QUAL2K, ICM, etc. and summarize past development efforts. As research continues, it is anticipated that improved process descriptions will be developed and will be integrated into the NSM.

\section{SUBJECT TERMS}

In-stream water quality

Nutrient Sub-Model (NSM)

16. SECURITY CLASSIFICATION OF:

\section{a. REPORT}

UNCLASSIFIED

b. ABSTRACT
UNCLASSIFIED

Water quality modeling

17. LIMITATION
OF ABSTRACT

\section{NUMBER OF PAGES}

c. THIS PAGE

UNCLASSIFIED

59 19a. NAME OF RESPONSIBLE PERSON

19b. TELEPHONE NUMBER (include area code) 